23 Keywords: Source-to-sink, Cenozoic, sediment flux, Africa, craton, continental margin

\author{
Jean-Louis Grimaud ${ }^{1,2}$ *, Delphine Rouby ${ }^{1}$, Dominique Chardon ${ }^{1,3}$, Anicet Beauvais ${ }^{4}$ \\ (1) Géosciences Environnement Toulouse, Université de Toulouse, CNRS, IRD, UPS, CNES, F-31400 \\ Toulouse, France
}
(2) now at MINES ParisTech, PSL Research University, Centre de Géosciences, 35 rue St Honoré, 77305 Fontainebleau Cedex, France

(3) IRD and Département des Sciences de la Terre, Université Ouaga I Professeur Joseph Ki-Zerbo, 01 PB 182 Ougadougou 01, Burkina Faso
(4) Aix-Marseille Univ, CNRS, IRD, Coll France, CEREGE, BP 80, 13545 Aix-en-Provence, Cedex 4, France

* corresponding author: jean-louis.grimaud@mines-paristech.fr Manuscript submitted to Basin Research, 25-Nov-2016

Revised manuscript, submitted 24 April 2017

Accepted, 11 June 2017

DOI: 10.1111/bre.12248

\title{
Cenozoic sediment budget of West Africa and the Niger delta
}




\section{ABSTRACT}

25 Long-term $\left(10^{6-7} \mathrm{yr}\right)$ clastic sedimentary fluxes to the ocean provide first-order constraints on the 26 response of continental surfaces to both tectonic and climatic forcing as well as the supply that

27 builds the stratigraphic record. Here we use the dated and regionally correlated relict lateritic

28 landforms preserved over Sub-Saharan West Africa to map and quantify regional denudation as

29 well as the export of main catchments for 3 time intervals (45-24, 24-11 and 11-0 Ma). At the

30 scale of West Africa, denudation rates are low $\left(\sim 7 \mathrm{~m} \mathrm{Myr}^{-1}\right)$ and total clastic export rate

31 represents $18.5 \times 10^{3} \mathrm{~km}^{3} \mathrm{Myr}^{-1}$. Export rate variations among the different drainage groups

32 depend on the drainage area and, more importantly, rock uplift. Denuded volumes and offshore

33 accumulations are of the same magnitude, with a noticeably balanced budget between the Niger

34 River delta and its catchment. This supports the establishment of the modern Niger catchment

35 before $29 \mathrm{Ma}$, which then provided sufficient clastic material to the Niger delta by mainly

36 collecting the erosion products of the Hoggar hotspot swell. Accumulations on the remaining

37 Equatorial Atlantic margin of Africa suggest an apparent export deficit but the sediment budget is

38 complicated by the low resolution of the offshore data and potential lateral sediment supply from

39 the Niger delta. Further distortion of the depositional record by intracontinental transient storage

40 and lateral input or destabilization of sediments along the margin have been identified in several

41 locations, prompting caution when deducing continental denudation rates from accumulation

42 only. 
Clastic sediments fluxes represent the bulk terrigenous supply to oceanic basins derived

46 from the dissection and erosion of continental surfaces (Fig. 1). They build the sedimentary

47 record along continental margins over geological timescale $\left(10^{5-7} \mathrm{yr}\right)$ and, together with chemical

48 fluxes, contribute to the global bio-geochemical cycles. The stratigraphic record may allow

49 retrieving paleo-environmental information such as the climatic variations, landform evolution

50 and vertical movements on the adjacent continental domains (Burbank, 1992; Molnar, 2004;

51 Clift, 2010), documenting the long-term response of landscapes to external forcing.

52 Comprehensible clastic fluxes are therefore first-order data to geomorphologists,

53 sedimentologists and geodynamicists to decipher sediment production, transfer and deposition in

54 its ultimate basin sinks (Allen, 2008; Fig. 1).

$55 \quad$ Clastic fluxes are usually obtained from sedimentary basin accumulations (e.g. Rust \&

56 Summerfield, 1990; Métivier et al., 1999; Guillocheau et al., 2012). Stratigraphy alone however

57 lacks information about catchment evolution (Bishop, 1995) and distribution of erosion within

58 the source region. Furthermore, temporary storage and later erosion of sediments may delay or

59 erase stratigraphic information (Sadler, 1981; Métivier \& Gaudemer, 1999; Jerolmack \& Paola,

60 2010). Sediment fluxes predicted from landscape evolution models are calibrated at micro- to

61 mesoscale $\left(\mathrm{m}^{2}\right.$ to $\left.\mathrm{km}^{2}\right)$ and short-term $\left(10^{1-4} \mathrm{yr}\right)$, and may not be representative of large

62 continental surfaces $\left(>10^{4} \mathrm{~km}^{2}\right.$ ) evolving at geological timescale (Simoes et al., 2010). Sediment

63 budgets comparing source and sink are therefore the most meaningful to understand relief

64 dynamics at geological timescales but are limited by the lack of constraints on the source

65 catchments and require making assumptions on their topographic and drainage evolution (e.g.

66 Leturmy et al., 2003; Campanile et al., 2008; Rouby et al., 2009; MacGregor, 2013). Better 
constraints on continent-scale surface evolution are required to calibrate long-term clastic fluxes

68 and the associated sedimentary basin evolution. Chardon, 2013) but integrate large continental catchments (i.e. $10^{6} \mathrm{~km}^{2}$; Fig. 2). Cratons are the

71 source of major clastic accumulations over long-lasting segments of passive margins in Africa

72 and worldwide, hosting extensive sediment archives as well as hydrocarbon resources (Bradley,

73 2008). The slow erosion rates of cratons result in the preservation of geomorphic markers as

74 illustrated by the relicts of lateritic landscapes of tropical shields derived from Meso-Cenozoic

75 intense weathering periods associated to warm climate (Tardy \& Roquin, 1998; Zachos et al.,

76 2001; Beauvais \& Chardon, 2013; Fig. 3). Quantifying erosion using these relict landforms has

77 proven useful to apprehend the denudation rates and landform evolution of cratonic sediment

78 routing systems (Beauvais \& Chardon, 2013; Grimaud et al., 2015).

This study presents a comparison between the volumes eroded and exported from the

80 main catchments of Sub-Saharan West Africa and the sediments preserved in the adjoining

81 continental margin basins of the Equatorial Atlantic Ocean during the Cenozoic. We use relict

82 lateritic landforms and recently published paleo-drainage maps (Chardon et al., 2016) to

83 constrain continental clastic exports, and a measure of offshore accumulations. We compare

84 accumulation with erosion between the Niger delta and its catchment and between the remaining

85 portion of the Equatorial Atlantic margin of Africa (i.e. without the Niger delta) and its sources.

86 Accumulated and eroded volumes fall within the same range allowing discussion of the influence

87 of rock uplift, catchment evolution and sediment transfers on sediment budgets. 
The studied area comprises a $4 \times 10^{6} \mathrm{~km}^{2}$ cratonic surface extending from the Senegal-

91 Mauritania basin to the west and to the Hoggar and Adamaoua massifs to the northeast and

92 southeast, respectively (Fig. 2). Major river systems (the Niger, Senegal and Volta rivers)

93 currently collect sediment supplied to the continental margin basins of this domain. The Niger

94 catchment $\left(2.3 \times 10^{6} \mathrm{~km}^{2}\right)$ drains the main topographic massifs: the Guinean rise, the southern

95 Hoggar massif and the Jos plateau and the Adamaoua massif bounding the Benue trough (Fig. 2).

96 At the outlet, the Niger delta surface is $26 \times 10^{3} \mathrm{~km}^{2}$ and its Cenozoic sediment thickness exceeds

$979 \mathrm{~km}$ (Fig. 2). In contrast, the remaining portion of the Equatorial Atlantic of Africa (i.e.

98 excluding the Niger delta; Fig. 2), fed by rivers such as the Volta, has a larger basin surface (750

$\left.99 \times 10^{3} \mathrm{~km}^{2}\right)$ and a thinner Cenozoic sediment cover ( $<3 \mathrm{~km}$; Helm, 2009).

100 The West African bedrock is composed of Archean and Paleoproterozoic basement

101 bounded by mobile belts of Panafrican ( 800 - $450 \mathrm{Ma})$ and Variscan ( 360 - $250 \mathrm{Ma})$ ages

102 (Villeneuve, 2005; Feybesse et al., 2006). It is overlain by Neoproterozoic to Phanerozoic

103 sedimentary series, the main depocenter of which is located in the Taoudeni basin (Villeneuve,

104 2005; Fig. 2). Cenozoic sedimentary series preserved onshore include Eocene carbonates found

105 in the Senegal-Mauritania, Iullemmeden and Togo-Benin basins overlain by Lutetian to Rupelian

106 (49-29 Ma) continental deposits known as the Continental Terminal (Chardon et al., 2016). Sub-

107 Saharan West Africa is considered as tectonically stable since Late Cretaceous rifting in the

108 Iullemmeden, Chad and Benue basins, and has mostly undergone long-wavelength lithospheric

109 deformation since (Ye et al., 2017 and references therein). The Central Atlantic Ocean opened

110 since the Late Triassic and the Equatorial Atlantic during the Late Early Cretaceous (Brownfield

111 \& Charpentier, 2006; Moulin et al., 2010; Labails et al., 2010; Ye et al., 2017; Fig. 2). The

112 offshore Cenozoic stratigraphic record in West Africa is characterized by a shift in sedimentation 
113 during the Oligocene. The Paleocene-Eocene was a period of relatively high sea level, intense

114 inland weathering and preferential deposition of chemical sediments (i.e. carbonates and

115 phosphates) in the intracratonic and marginal basins (Fig. 3) (Millot, 1970; Valeton, 1991). The

116 Oligo-Miocene period marked the increase of clastic sedimentation in continental basins and

117 adjacent passive margins (Séranne, 1999; Burke et al., 2003). A paleo-Niger delta was likely

118 established in the Benue during the Paleocene (Reijers, 2011) but the main delta progradation

119 started at 34 Ma (Doust \& Omatsola, 1990). In the literature, the Oligocene shift in sedimentation

120 has been interpreted as resulting from either the effect of greenhouse to icehouse climatic

121 transition (Séranne, 1999) or to the continental uplift of Africa contemporaneous with the

122 development of its "basin-and-swell” topography driven by the growth of several hotspot swells

123 such as the Hoggar, the Adamaoua or the Jos Plateau (Burke, 1976, 1996; Burke et al., 2003; Fig.

124 2). Using the reconstructed geometries of dated paleolandscapes, Chardon et al. (2016) suggested

125 the establishment of the modern Niger River watershed in, at least, the Late Oligocene (29 Ma)

126 and possibly the Eocene-Oligocene boundary (34 Ma) i.e., at the acceleration of the progradation

127 of the Niger delta. The major drainage reorganization and the growth of the Hoggar hot spot

128 swell would explain the increase in clastic fluxes toward the Niger Delta (Chardon et al., 2016).

129 Post-Eocene clastic fluxes would also have been increased by uplift-related erosion along a

130 marginal upwarp inherited from Mesozoic rifting that extended from the Jos Plateau to the

131 Guinean rise (Beauvais \& Chardon, 2013). The marginal upwarp is a 300 to $800 \mathrm{~km}$ wide strip of

132 relief, running parallel to the coast. It is interpreted as initiating during the rifting and maintained

133 by lithosphere flexure, erosional unloading and associated sediment loading on the adjoining

134 margin (Gilschrist \& Summerfield, 1994; Beaumont et al., 2000). 


\section{DENUDATION CHRONOLOGY}

Sub-Saharan West Africa was located within the tropical belt throughout the Cenozoic,

138 allowing several generations of lateritic regoliths to be produced regionally. Rivers removed parts

139 of these regoliths to form a unique geomorphic sequence of stepped paleolandscapes capped by

140 duricrusts (Michel, 1973; Fig.3a). These landscapes were not sub-continental flat planation

141 surfaces as advocated by King (1962) but composite landscapes, the relief of which increased

142 throughout the Cenozoic (Figs. 4 and 5; Beauvais \& Chardon, 2013; Grimaud, 2014; Grimaud et

143 al., 2015). Each member of the sequence has a specific morphology and type-regolith that reflect

144 variation of weathering intensity and slope erosion processes (Boulangé et al., 1973; Grandin,

145 1976; Tardy \& Roquin, 1998). This allows for correlations of each type of paleo-landscape

146 remnant on a regional scale (e.g. Fig. 4; Beauvais \& Chardon, 2013; Grimaud et al., 2014). The

147 regolith formed by lateritic weathering of the bedrock during long $\left(>10^{6} \mathrm{yr}\right)$, warm and humid

148 climatic periods (Fig. 3b). Weathering resulted in leaching of mobile elements and the

149 accumulation of less mobile iron and/or aluminum in the shallow depths of the regolith profiles.

150 Ultimately, the duricrusting of the upper horizons occurred when the weathering profiles became

151 disconnected from the local base levels (i.e., following river incision and/or the return to drier

152 climatic conditions). Hence, the terminal weathering age of a regolith profile capped by a

153 duricrust is considered as marking the abandonment of the associated paleo-surface (i.e. Fig. 3).

The first member of the West Africa geomorphic sequence (S1; Fig. 3) is a surface of

155 continental scale, known as the "African Surface”, formed under a humid equatorial climate from

156 the Late Cretaceous to the Eocene (Beauvais \& Chardon, 2013). Weathering shaped a low-relief

157 landscape and formed bauxites (i.e. Al-Fe crust; Figs. 3 and 4). The S1 bauxite was abandoned to

158 form an incised landscape during the development of the next member of the sequence, the so- 
called "Intermediate” surface (S2; Fig.3), ultimately capped by a ferricrete. The S2 surface was

160 dissected and abandoned during the development of the S3 erosion surface ("High glacis" in the

161 French literature). S3 is a pediment, i.e., a gently sloping concave-upward surface, formed under

162 semi-arid to arid climate during which stable base level and high seasonality favor surface

163 sheetwash during the monsoon (Hadley, 1967; Grandin, 1976). Ferricretes capping S3 formed

164 under more contrasted humid conditions (Fig. 3b). S3 ferricrete often cements a detrital layer that

165 contains clasts of S1 and S2 crusts (Boulangé et al., 1973; Grandin, 1976; Grimaud et al., 2015).

166 Hence S1, S2 and S3 remnants have first order distinctive landform-regolith associations that

167 allow for regional correlation (Beauvais \& Chardon, 2013; Grimaud et al., 2014).

Ages of laterite formation were bracketed by ${ }^{40} \mathrm{Ar}-{ }^{39} \mathrm{Ar}$ dating of supergene K-rich $\mathrm{Mn}$

169 oxides such as cryptomelane $\left[\mathrm{K}_{\mathrm{x}}\left(\mathrm{Mn}^{3+}\right)_{\mathrm{x}}\left(\mathrm{Mn}^{4+}\right)_{8-\mathrm{x}} \mathrm{O}_{16}\right]$ in Tambao, Burkina Faso (Beauvais et

170 al., 2008), and sulphates as alunite / jarosite in Syama, Mali (Vasconselos et al., 1994a; Fig. 3b).

171 These minerals formed under weathering and oxidation conditions converting the bedrock into

172 lateritic regolith and are therefore useful tracers of major weathering periods and associated

173 formation of duricrusted surfaces. The S1 surface was abandoned after 45 Ma, S2 after 24 Ma

174 and S3 after 11 Ma (Beauvais \& Chardon, 2013; see also Grimaud et al., 2015; Figs 3 and 4). The

175 radiometric ages of the West African geomorphic sequence (Fig. 3b) are consistent with other

176 time-constraints. The weathering of the bauxitic paleolandsurface is correlated to chemical

177 marine sedimentation in Sub-Saharan West Africa during the Early-Mid Eocene interval (Millot,

178 1970), while the S2 ferricrete caps the weathering profiles developed upon Late Eocene-

179 Oligocene “Continental Terminal” alluvial deposits (Chardon et al., 2016). 


\section{Regional distribution and mapping of lateritic relict landforms}

We referenced S1, S2 and S3 relicts over West Africa (Fig. 5) using a combination of

fieldwork (in Benin, Burkina Faso, Mali, Niger, Guinea and Senegal), descriptions from existing

185 literature (e.g. Newill \& Dowling, 1968; Fölster, 1969; Eschenbrenner \& Grandin, 1970;

Boulangé \& Eschenbrenner, 1971; Michel 1973, 1977a, 1977b; Boulangé et al., 1973; Grandin \&

187 Hayward, 1975; Grandin, 1976; Burke, 1976; Fritsch, 1978; Thomas, 1980; Rognon et al., 1983;

Adegoke et al., 1986; Bowden, 1987; Boulangé \& Millot, 1988; Durotoye, 1989; Teeuw, 2002;

Thomas, 1994) (recent compilations in Beauvais \& Chardon, 2013; Grimaud, 2014) and

combined analyses of topography and satellite images. Field stations and the full compilation of

the references can be found in the Supporting Information. We identified and reported the

192 elevation of S1, S2 and S3 remnants based on their geomorphology and regolith type (see below).

193 In order to further constrain the regional geometries of the surfaces, we also surveyed additional

194 data such as topographic massifs summits (B points), Early-Mid Eocene carbonates (C points)

195 and lower parts of S1 weathering profile remnants (D points) (Chardon et al., 2016). Figure 5

196 illustrates how these data points were used to reconstruct surface geometries.

$\mathrm{S} 1$ relicts dominate West African landscapes in the form of bauxitic mesas capped by a

flat duricrust of beige to pink color reflecting the presence of aluminum (Figs. 4a and 5b). In the

199 Guinean rise and eastward (i.e. upwarp domain; Fig. 2), the S1 relicts are preserved 400 to $600 \mathrm{~m}$

200 above modern rivers (see Beauvais \& Chardon, 2013). This local relief decreases towards the

201 coast and the continental interiors, where S1 relicts are less than $60 \mathrm{~m}$ above the Niger River in

202 the Inland Niger delta (Grimaud et al., 2014; Figs. 2 and 4c).

S2 ferricretes have red-purple colors on satellite images due to their high iron content and

204 a morphological aspect different from S1 and S3 (Figs. 4 and 5b). S2 relicts are usually 
205 distributed 50-200 m, and locally up to $400 \mathrm{~m}$, vertically in the landscape below S1 remnants

206 (Grandin, 1976; Beauvais \& Chardon, 2013). They are either connected to bauxite relicts,

207 forming convex-upwarp surface on the slopes of S1 mesas (Figs. 3a, 4a, 4b and), or occur

208 stepped under S1 relicts. It has been shown that the elevation of S2 relicts decreases from the

209 divides to the outlet of West African catchments, following the geometry of the main watersheds

210 and implying that the S2 drainage was similar to the modern one (Beauvais \& Chardon, 2013;

211 Grimaud et al., 2014; Chardon et al., 2016; Figs. 4a, 4b and 4d).

212 S3 ferricretes can usually be identified in the field by their embedded conglomerate

213 deposits and their brown to grey color on satellite images. S3 relicts usually form gently dipping

214 plateaus of several square kilometers in area with concave-up profiles (Figs. 3a and 4). S3

215 plateaus are easily identified when radiating from the piedmont of S1 or S2 mesas (Figs. 4a and

216 4b). The downstream parts of S3 relicts are usually 10-100 m above modern rivers and well

217 preserved throughout West Africa, suggesting modest post-11 Ma landscape dissection and

218 denudation (Beauvais \& Chardon, 2013; Grimaud et al., 2015; Fig. 4).

219

220 Quantification of exported volumes and conversion to sediment fluxes

We estimated denudation volumes and the associated export to offshore basins using

222 regional reconstructions of S1, S2 and S3 surface geometries, and the modern topography. S1, S2

223 and S3 geometries were reconstructed using the DSI method (Mallet, 1992) that allows building

224 complex geologic surfaces (see Chardon et al., 2016). By subtracting these surfaces, we obtained

225 the S1-S2, S2-S3 and S3-modern elevation differences maps corresponding to incremental

226 denudation maps for the 45-24, 24-11 and 11-0 Ma intervals (Fig. 6) as well as the total 
227 denudation map since 45 Ma (i.e. S1-modern map; Fig. 7). S1 and S2 surfaces geometries are

228 those published by Chardon et al. (2016) and S3 surface is from this study.

The sediment volumes stored in continental sedimentary basins during the S1-S2 interval 230 (blue colors on Figure 6b) were subtracted to the eroded volumes to obtain the volumes exported 231 to the continental margin $\left(V_{e x}\right)$ (Table 1). These storage volumes were calculated between the S1 232 and S2 surface geometries. They are actually larger than the volumes currently preserved in the 233 intracratonic sedimentary basins because of erosion after 24 Ma (see Fig. 8 for an illustration in 234 the Iullemmeden basin). We developed an analysis of uncertainties on the exported volumes estimates. Overall, we 236 found errors values around 10-30\% (see Table 1 and Supporting Information). The first 237 uncertainty was estimated for the construction of surface geometries. For that, we built replicates 238 of the S2 and S3 surfaces, respectively S'2 and S'3, to measure the variability of their geometries.

239 S'2 and S'3 are less realistic and less elevated than S2 and S3 surfaces (Figs. SI2 and SI3)

240 because they were built using only S2 or S3 points respectively, i.e. they were not enforced at the 241 location of the anterior surfaces or forced by the topography. The uncertainties on surface 242 geometries were then measured by the elevation difference between S2 and S'2 and S3 and S'3 243 (Fig. SI3). The second uncertainty related to the partitioning of erosion volumes of denudation maps, 245 built at the scale of West Africa, between four drainage groups (Senegambia, Short Atlantic 246 drainages, Long Atlantic drainages and the Niger catchment; Fig. 6a). In this study, we used the 247 paleo-drainage maps of Chardon et al. (2016), where the drainage divide positions themselves are 248 located within an area of uncertainty (i.e. Figs. 6b and 6c). We calculated the volume eroded 249 within this uncertainty area to estimate the volume uncertainty associated to the divide location. 
251 represents the type-material eroded from the West African continental domain during the

252 Cenozoic (Beauvais and Chardon, 2013). The density and porosity of the eroded lateritic regolith

253 is different from bedrock (e.g. Grimaud et al., 2015). Exported volume ( $\left.V_{e x}\right)$ was corrected for the

254 lateritic regolith porosity, $\varphi$, which varies from 10 to 40 \% (Valeton, 1991; Boulangé, 1984;

255 Beauvais \& Colin, 1993; Thomas, 1994). We thus estimated the clastic exported solid volume

256 assuming a 25\% mean porosity in the regolith (Table 1). Regolith bulk density is 2,000 $\mathrm{kg} \mathrm{m}^{-3}$

257 (Valeton, 1991), which corresponds to a grain density $\rho$ of 2,650 $\mathrm{kg} \mathrm{m}^{-3}$. We estimate the clastic

258 yields $\gamma$ of each drainage group using:

$259 \gamma=\frac{V_{e x} \cdot(1-\varphi) \cdot \rho}{1000 \cdot A \cdot \Delta_{t}}$

where $A$ and $\Delta_{t}$ are the catchment area and the time-interval, respectively, and $\gamma$ has unit

261 of mass per unit area per time $\left(\mathrm{t} \mathrm{km}^{-2} \mathrm{yr}^{-1}\right)$. Calculations of clastic exported solid volumes and

262 clastic yields therefore assumed that most eroded material was regolith. Because in West Africa

263 bedrock outcrops are rare, erosion rates are slow and regolith mantles are thick, the assumption

264 seems reasonable (Grimaud et al., 2015). This also implies that a sizeable portion of the denuded

265 volume, which we did not quantify, was exported as solute load. However, in area with fast

266 denudation rates, the eroded material may locally be only moderately weathered. In that case, the

267 actual clastic export was higher than our estimate, which should therefore be considered as

268 minimum. 
272 porosity and non-clastic material such as volcanics and carbonates) following the method of

273 Guillocheau et al. (2012), based on regional geological cross-sections (Fig. 9). The calculation

274 technique, non-clastic material and remaining porosity corrections, and uncertainties estimations

275 are presented in the Supporting Information.

276 In the Niger delta domain, we used the four sections published by Haack et al. (2000) that

277 encompass most of the Cenozoic depocenters (Figs. 9a and 9b). Given the biostratigraphic age

278 constraints available for the sediments, these sections allowed measuring accumulation at higher

279 time resolution (10 $10^{5-6} \mathrm{yr}$; Fig. 9d; Table 2$)$ than the denudation maps. Hence, we recalculated

280 accumulations for the 45-23, 23-11.6 and 11.6-0 Ma intervals to allow for comparison with the

281 erosion chronology (Fig. 9e; Table 2). In the Equatorial Atlantic, we used 6 sections (after de

282 Caprona, 1996; MacGregor et al., 2003) that only encompass the proximal parts of the margins.

283 We then used the extrapolation of these cross-sections to the abyssal plain proposed by Helm

284 (2009) (Fig. 9c; Supporting Information) to include volume accumulated across the entire

285 sedimentary wedge and to take into account erosion from, or by-pass of, the continental shelf

286 (Fig. 9f). Volume for the 45-33.9 Ma interval was recalculated using the accumulation rate of the

287 55.8-33.9 Ma interval (Table 1).

289 RESULTS

290 Spatial and temporal denudation patterns

291 Incremental (45-24, 24-11 and 11-0 Ma) and total (45-0 Ma) denudations are

292 heterogeneous at regional scale (i.e. Figs. 6 and 7). Overall, denudation is greater in the eastern 
swells (i.e., massifs located to the east of the dashed line in Figures 6b, 6c and 6d) and along a 294300 to $800 \mathrm{~km}$ wide strip running parallel to the coast (i.e. from the Jos Plateau to the Guinean 295 rise and the Tagant) that we interpret as a marginal upwarp following Beauvais \& Chardon 296 (2013). Total denudation exceeds $1500 \mathrm{~m}$ in the Hoggar massif and ranges between 400 and 1000 297 m along the marginal upwarp (Figs. 7 and 8a). Elsewhere, the total denudation is usually less than $298400 \mathrm{~m}$. Some onshore accumulation (i.e. negative erosion) is observed in the Togo-Benin, 299 Senegal-Mauritania and Iullemmeden basins, where up to $400 \mathrm{~m}$ were accumulated during the 300 45-24 Ma interval (Figs. 6b and 8a). Post-24 Ma denudation is low in these basins ( $<100 \mathrm{~m}$;

301 Figs. 6c and 6d) with the noticeable exception of the northern Iullemmeden basin where 302 geological sections show that at least half of the "Continental Terminal” deposits were eroded 303 (Fig. 8a).

From 45 Ma to the present, denudation was high in the Hoggar massif with a maximum during the 24-11 Ma interval (up to 1200 m; Fig. 6). During that period, denudation was more broadly distributed (i.e. it extended toward the North Iullemmeden basin; Fig. 8a) than during the 45-24 and 11-0 Ma intervals. Denudation was more homogenously distributed on the marginal upwarp between 45 and 24 Ma than after 24 Ma. On the Guinean rise (i.e. mostly the Short Atlantic drainages group), relatively high denudation depths were maintained at all times (Fig. 6).

310 Similarly, high denudation depths were recorded from 45 to 11 Ma by the Long Atlantic 311 drainages group in an area that is currently lying low in comparison to the neighboring Guinean 312 rise (Fig. 2). In the Long Atlantic drainages and Niger catchment groups, denudation depths are 313 overall lower during the 11-0 Ma interval (Fig. 6). In the Senegambia group, denudation 314 increased after $11 \mathrm{Ma}$ in both the Tagant massif and the northwestern slope of the Guinean Rise 315 (Beauvais \& Chardon, 2013; Figs. 2 and 6d). In the Benue trough, the tabular Paleocene Kerri- 
316 Kerri Formation is capped by a duricrust comparable to the Intermediate ferricrete (Newill \& 317 Dowling, 1968; Adegoke et al., 1986), which allows constraining the incision of these deposits 318 after the abandonment of S2 surface (i.e. 24 Ma; Fig. 3). A geologic section suggests that Benue 319 valley denudation did not exceed $200 \mathrm{~m}$ since $24 \mathrm{Ma}$, corresponding to a maximum denudation 320 rate of $8.4 \mathrm{~m} \mathrm{Myr}^{-1}$ (Fig. 8b).

These data show that denudation rates are overall low in West Africa since $45 \mathrm{Ma}$ (mean 322 denudation rate of $7.4 \mathrm{~m} \mathrm{Myr}^{-1}$; Table 1). They are higher in the Hoggar massif (i.e. larger than

$32330 \mathrm{~m} \mathrm{Myr}^{-1}$ ) and the marginal upwarp (up to $10 \mathrm{~m} \mathrm{Myr}^{-1}$ ), where some temporal variations are 324 also observed. Denudation rates remain lower than $5 \mathrm{~m} \mathrm{Myr}^{-1}$ in the remainder of West Africa.

\section{Export at the scale of major catchments}

In total, the West African sub-continent exported $834 \times 10^{3} \mathrm{~km}^{3}$ of solid clastic sediments 328 to the ocean (Table 1) since 45 Ma. These clastic volumes were distributed between the major 329 drainage groups (Figs. 6 and 7): $74 \times 10^{3} \mathrm{~km}^{3}$ from the Senegambia, $83 \times 10^{3} \mathrm{~km}^{3}$ from the Short 330 Atlantic drainages, $170 \times 10^{3} \mathrm{~km}^{3}$ from the Long Atlantic drainages and $430 \times 10^{3} \mathrm{~km}^{3}$ from the 331 Niger catchment (Table 1). At first order, exported solid volumes therefore increase with the size 332 of the contributing area. Results also show that the export is modulated by onshore storage of 333 sediments that we subtracted. Hence $16 \%\left(12 \times 10^{3} \mathrm{~km}^{3}\right)$ of the total clastic export from 334 Senegambia is stored onshore in the Senegal-Mauritania basin whereas only $5 \%$ of the total 335 clastic export from the Niger catchment is preserved in the Iullemmeden basin. In the Niger 336 source-to-sink system, we did not measure denudation in the Benue trough and surrounding 337 massifs (Figs. 6 and 7) because the rare descriptions of regolith (Fritsch, 1978; Guillocheau et al., 
2015) would not allow to rigorously integrating them to the denudation chronology. However, we

339 have estimated and added a Benue trough export to compare the clastic export from the Niger

340 catchment to the accumulations in the Niger delta. We estimated that the Benue contributed a

341 solid clastic volume of ca. $187 \times 10^{3} \mathrm{~km}^{3}$ assuming that the average West African denudation rate

342 of $7.4 \mathrm{~m} \mathrm{Myr}^{-1}$ applies to this area $\left(\sim 0.77 \times 10^{6} \mathrm{~km}^{2}\right.$; Table 1$)$. This rate is compatible with

343 observations in the Benue valley (see previous section). Denudation was potentially higher,

344 enhanced by Neogene uplift, in the surrounding massifs (Burke, 1976). However, the

345 preservation of Neogene volcanics and lateritic regoliths in the Jos Plateau and Adamaoua

346 massifs (Boulangé \& Eschenbrenner, 1971) suggests that denudation rates were probably much

347 lower there than in the Hoggar area. In parallel, the neighboring Chad basin has been constantly

348 subsiding and trapping sediment since at least 24 Ma (Burke, 1976), suggesting that no sediment

349 was diverted from the basin into the Benue trough (see Chardon et al., 2016). Using a mean West

350 Africa denudation rate seems therefore reasonable to estimate the erosion in the area of the Benue

351 Trough. In line with these hypotheses, the resulting total clastic export of the Niger-Benue

352 catchment reaches $630 \pm 172 \times 10^{3} \mathrm{~km}^{3}$ since $45 \mathrm{Ma}$ (Table 1). The Hoggar swell area has

353 contributed ca. $66 \%$ of this volume.

Temporal variations in clastic export reflect the evolution of denudation rate and drainage.

355 In most drainage groups, clastic export rates were lower during the 45-24 Ma interval than during

356 the 24-11 Ma interval (Figs. 7b-7e). Within the Senegambia drainage group, clastic export rate

357 was slightly higher in the 11-0 Ma interval. In contrast, clastic export rate was steady for the

358 Short Atlantic drainages group (Figs. 7b and 7c). In the Long Atlantic drainages group and the

359 Niger catchment, export rates were lower during the 11-0 Ma interval than during the 24-11 Ma

360 interval (Figs. 7d and 7e). The highest uncertainties on clastic export rates are estimated for in the 

between 45 and 24 Ma (Chardon et al., 2016; Table 1; Supporting Information). Hence the overall export trends among drainage groups appear regionally consistent in between the 45-24 and 24-11 Ma intervals and more contrasted in between the 24-11 and 11-0 Ma intervals.

Offshore accumulation

Offshore domains differ in their structural and sediment accumulation patterns (Fig. 9a).

368 For the Niger delta, the sections used to estimate accumulation encompass the major part of the 369 Cenozoic sedimentary wedge located along the margin (Fig. SI4). These sections show thick 370 marginal clinoforms that have prograded over $150 \mathrm{~km}$ since the Oligocene and that are affected 371 by faulting and folding (Figs. 8b and 9b). Along the remaining part of the Equatorial Atlantic 372 margin, $90 \%$ of the Cenozoic wedge is spread over the abyssal plain and extends over 300-600 373 km offshore (Fig. 9c).

374 Accumulation rates for the Niger delta can be estimated at higher resolution than 375 denudation (Fig. 9d). These rates show a steady increase from ca. 5 to $10 \times 10^{3} \mathrm{~km}^{3} \mathrm{Myr}^{-1}$ 376 between 45 and $16 \mathrm{Ma}$. After $16 \mathrm{Ma}$, the accumulation rates increased to more than $20 \times 10^{3} \mathrm{~km}^{3}$ $377 \mathrm{Myr}^{-1}$. A peak in accumulation rate $\left(40 \times 10^{3} \mathrm{~km}^{3} \mathrm{My}^{-1}\right)$ is recorded between 5.3 and 1.8 Ma, 378 followed by a relative decrease after 1.8 Ma (Jermannaud et al., 2010). Solid accumulation rates, 379 re-sampled for long-term intervals, are respectively ca. 5, 12 and $28 \times 10^{3} \mathrm{~km}^{3} \mathrm{Myr}^{-1}$ during the 380 45-23, 23-11 and 11-0 Ma intervals. These data show that a larger volume of Neogene sediments 381 is preserved in the delta compared to Paleogene sediments. The resulting total clastic 382 accumulation since $45 \mathrm{Ma}$ is about $580 \times 10^{3} \mathrm{~km}^{3}$ (Table 2). This number is remarkably 
consistent with -although slightly lower than- the calculated clastic volume exported by the Niger-Benue catchment since $45 \mathrm{Ma}$ (ca. 630 × $10^{3} \mathrm{~km}^{3}$; Table 1).

Along the rest of the margin, available data have a lower resolution than in the Niger delta, especially in the abyssal plain, and imply larger uncertainties (Fig. 9; see Helm, 2009). Accumulated volumes computed for the three time intervals suggest a long-term pattern of accumulation rate comparable to that of the Niger delta. The volumes are ca. 65,85 and $300 \times 10^{3}$ $\mathrm{km}^{3}$ during the 45-33, 33-21 and 21-0 Ma intervals, respectively (Fig. 9f). The total accumulated clastic volume since $45 \mathrm{Ma}$ is $450 \pm 120 \times 10^{3} \mathrm{~km}^{3}$. This is 2-4 times higher than our estimate of exported clastic volumes $\left(151 \times 10^{3} \mathrm{~km}^{3}\right)$ from the source area.

\section{DISCUSSION}

\section{Cenozoic sediment budget}

Surficial mass transfers from source to sink and the associated (un) loading of the crust are key aspects of the topographic evolution and stratigraphic record of passive margins (Rouby et al., 2013). Our study provides independent volumetric estimations of denudation at a subcontinental scale over the Cenozoic using relict paleolandforms and of accumulation using offshore regional sections. The main insight from our study is the fairly well balanced sediment budget between the Niger delta and its source area. Such a finding supports the paleodrainage reconstruction of Chardon et al. (2016) who suggested the establishment of the modern Niger River watershed since at least the Late Oligocene (29 Ma). The modern-like Niger River catchment since at least 29 Ma collected sediments from a ca. 2 x $10^{6} \mathrm{~km}^{2}$ catchment and transferred the large eroded volumes derived from the Hoggar hot spot swell to the ocean. The 
405

406

407

408

409

410

411

412

413

414

415

416

417

418

419

420

421

422

423

424

425

426

427

antiquity of the Niger catchment appears as a prerequisite to the large clastic accumulations in the Niger delta given the low denudation rates (5-30 $\left.\mathrm{m} \mathrm{Myr}^{-1}\right)$ at the scale West Africa.

Although our estimations fall within the same order of magnitude, we estimated a deficit on the volume of sediments exported by the Long Atlantic drainages group with respect to the accumulation along the Equatorial Atlantic margin they have fed (Fig. 9f; Table 1). Geometries of the offshore geological sections are, however, not well constrained and were deduced from low-resolution geophysical data with limited age constraints (Emery et al., 1975). Thus, an uncertainty of merely ten meters thickness on the distal geometry of a stratigraphic horizon may have significant repercussions on volume estimation in a basin as large as the Equatorial Atlantic, leading to underestimation or overestimation of accumulation. Clastic sediment budgets of the abyssal plains can further be affected by additional aeolian dust input from the Sahara (Windom, 1975), and more importantly by reworking by longitudinal bottom currents (Séranne and Nzé Abeigne, 1999; Anka et al., 2009). Some sediments derived from the Niger catchment may also have by-passed the delta toe and have been deposited on these parts of the Equatorial Atlantic, further complicating the sediment budgets. This is supported by the westward extension of the Niger delta (Fig. 2) and consistent with the fact that, in our estimation, accumulation is slightly lower than denudation in the Niger source-to-sink budget. Future studies constraining westward sediment transfer in the western Niger delta would help to decipher the apparently low export of the Long Atlantic drainages group.

We measured a difference between the volumetric accumulation rate of the Niger delta ( $\left.30 \times 10^{3} \mathrm{~km}^{3} \mathrm{Myr}^{-1}\right)$ and the export rate of the Niger catchment $\left(\sim 12 \times 10^{3} \mathrm{~km}^{3} \mathrm{Myr}^{-1}\right)$ during the 11-0 Ma interval (i.e. Fig. 7e and 9e). Assuming that the biostratigraphy used by Haack et al. (2000) is accurate, this difference could be explained by post-11 Ma erosion of sediments that 
428 were previously stored within the Niger sediment routing system, particularly on the shelf. As an

429 analogy, the widespread erosion of Miocene sediments stored on the continent or the shelf has led 430 to such reworking on the neighboring South Atlantic margin (e.g. Lavier et al., 2001; Walford \&

431 White, 2005; Linol et al., 2014). In the study area, reworking of Cenozoic sediments is supported 432 by the incision of large canyons in the Niger delta (Doust \& Omatsola, 1990) and the removal of 433 at least $50 \%$ of the former "Continental Terminal” after $24 \mathrm{Ma}$ in the Iullemmeden basin (see 434 geological section in Fig. 8a). Overall, the discrepancy between accumulation and erosion is a 435 point of caution when deducing denudation rates and paleo-sediment fluxes from the 436 accumulation record only. Indeed, if the 11-0 Ma clastic deposits are partly composed of recycled 437 material, their volume may overestimate continental denudation after $11 \mathrm{Ma}$, and underestimate 438 denudation before that time.

\section{Erosion dynamics in a non-orogenic domain}

Our maps show that denudation is very heterogeneously distributed across West Africa as 442 well as within each drainage group. Regional denudation patterns suggest an influence of long443 wavelength rock uplift (> 300 km) (Figs. 7 and 8; Chardon et al., 2016). Denudation focused on 444 the Hoggar suggests a rock-uplift pattern with $>700 \mathrm{~km}$ radius (Fig. 7a) related to mantle 445 dynamics (Burke et al., 2003; Chardon et al., 2016). Recently published apatite (U-Th)/He 446 thermochronological data indicate Cenozoic denudation in the Hoggar of 1-2 km between $78 \pm$ $44722 \mathrm{Ma}$ and $13 \pm 3$ Ma (Rougier et al., 2013), which is consistent with our estimation ( $1.5 \mathrm{~km}$; 448 Fig. 8a). Because we did not find the equivalent of S1 there, it is likely that we have even slightly 449 underestimated the denudation of the Hoggar for the 45-24 Ma interval. Nevertheless, the eroded 450 material derived from the Hoggar swell was instrumental in obtaining the volume accumulated in 
451 the Niger delta. As an illustration, applying the mean denudation rate of the other drainage groups

452 (i.e. $6.6 \mathrm{~m} \mathrm{Myr}^{-1}$ ) over the Niger catchment for $45 \mathrm{Ma}$ would have only resulted in only ca. $280 \mathrm{x}$ $45310^{3} \mathrm{~km}^{3}$ clastic volume exported to the Niger delta instead of the ca. $450 \times 10^{3} \mathrm{~km}^{3}$ we estimated

454 (Table 1). This simple calculation supports that forcing by mantle dynamics is a first-order

455 process for enhancing the sediment export from the African continent (Burke et al, 2003).

West of the dashed line in Fig. 7, maximum denudation depths within the upwarp domain

457 suggest some rock uplift associated with flexure along the passive margin (Beauvais \& Chardon,

458 2013; Grimaud et al., 2014). In detail, denudation histories vary across the different segments

459 along the margin, indicating a complex evolution. For example, erosion rates decreased along

460 major valleys of the Long Atlantic drainages between the 24-11 and 11-0 Ma intervals during the

461 progressive dissection of the upwarp, while they remained high in the Guinean Rise (i.e.

462 Senegambia and Short Atlantic drainages; Fig. 6). These different erosion dynamics resulted in

463 contrasted post-24 Ma evolution of clastic export rates in these drainage groups (Fig. 7b, 7c and

464 7d), resulting in source-to-sink systems that are not monotonous along the marginal upwarp. The

465 variability of erosion rates may tentatively be related to uplift rate variations along the continental

466 margin. Potentially, the stretching of a heterogeneous lithosphere or a non-cylindrical margin

467 during the rifting stage generates potentially complex, laterally variable uplift patterns, which

468 may be maintained long after rifting (Chardon et al., 2013; Rouby et al., 2013), leading to

469 unevenly distributed erosion rates.

$470 \quad$ Our analysis shows that dated relict lateritic landforms are reliable markers of post-rift

471 denudation of continental passive margins and adjacent cratonic domains with sufficient spatial

472 and temporal resolution. The variability of erosion histories along the margin shows (similarly to

473 Pazzaglia \& Gardner (1994) along the US Atlantic margin) that modern topography and paleo- 
474 denudation rates do not necessarily correlate (Figs. 2 and 7) and that independent geomorphic

475 markers are more robust than present-day digital elevation models to constrain surface dynamics

476 over geological timescales. West Africa is a non-orogenic domain where the erosion dynamics

477 may be compared to the adjoining offshore record thanks to a spatially constrained onshore

478 denudation chronology. In the future, new insights on the Cenozoic surface evolution of shields

479 and their bounding margins (e.g. Australia, Brazil, India, South Africa) will arise from the

480 mapping of relict landforms, whose lateritic cover has been dated using supergene minerals (e.g.

481 Vasconcelos et al., 1994a; 1994b; Vasconcelos \& Conroy, 2003; Bonnet et al., 2014; 2016; Riffel

482 et al., 2015; Beauvais et al., 2016).

\section{CONCLUSIONS}

485 We have quantified patterns and volumes of Cenozoic denudation and catchment export using 486 dated and regionally correlated relict lateritic landforms of Sub-Saharan West Africa. Overall

487 denudation rates are regionally low in this non-orogenic domain $\left(\sim 7 \mathrm{~m} \mathrm{Myr}^{-1}\right)$ but may increase

488 significantly locally with rock uplift, whether driven by mantle dynamics or lithosphere

489 deformation and flexure, as for example in the Hoggar hotspot swell and along a marginal

490 upwarp. Comparisons with clastic volumes accumulated offshore show a fairly balanced

491 sediment budget between the Niger catchment and its delta since $45 \mathrm{Ma}$. The Niger catchment

492 was established since at least $29 \mathrm{Ma}$ and allowed transporting sufficient clastic material to the

493 delta; in particular by collecting the erosion products of the growing Hoggar hotspot swell.

494 Accumulations along the remaining Equatorial Atlantic margin of Africa suggest an apparent

495 export deficit from its source but our estimation is poorly constrained by available offshore data, 496 and complicated by potential sediment input from the Niger delta. Sediment reworking shredding 
497 the depositional record is also suggested in several locations, prompting caution when deducing

498 continental denudation rates from accumulation only.

499

500 Acknowledgement:

501 This work was funded by WAXI, the CNRS and the ANR TopoAfrica (ANR-08-BLAN-572

502 0247-02) and supported by the gOcad consortium. We thank Michel Séranne and the SAFL

503 sediment dynamics group for fruitful discussions and suggestions as well as Damien Huygues

504 and Stéphane Perrouty for support. The manuscript also benefited from constructive reviews by

505 Frank Pazzaglia, Luc Lavier and Peter van der Beek. We acknowledge AMIRA International and

506 the industry sponsors, including AusAid and the ARC Linkage Project LP110100667, for their

507 support of the WAXI project (P934A) as well as the Geological Surveys/Departments of Mines

508 in West Africa as sponsors in kind of WAXI.

509 
511

ADEGOKE, O.S., AGUMANU, A.E., BENKHELIL, M.J. \& AJAYI, P.O. (1986) New stratigraphic, sedimentologic and structural data on the kerri-kerri formation, Bauchi and Borno States, Nigeria. J. Afr. Earth Sci., 5, 249-277.

ALLEN, P.A. (2008) From landscapes into geological history. Nature, 451, 274-276.

ANKA, Z., SÉRANNE, M., LOPEZ, M., SCHECK-WENDEROTH, M. \& SAVOYE, B. (2009) The long-term evolution of the Congo deep-sea fan: A basin-wide view of the interaction between a giant submarine fan and a mature passive margin (ZaiAngo project). Tectonophysics, 470, 42-56.

BEAUMONT, C., KOOI, H. \& WILLETT, S. (2000) Coupled tectonic-surface process models with applications to rifted margins and collisional orogens. In: Geomorphology and global tectonics (Ed. by M. A. Summerfield), 29-55. John Wiley \& Sons, Chichester UK BEAUVAIS, A., BONNET, N.J., CHARDON, D., ARNAUD, N. \& JAYANANDA, M. (2016) Very long-term stability of passive margin escarpment constrained by ${ }^{40} \mathrm{Ar} /{ }^{39} \mathrm{Ar}$ dating of K-Mn oxides. Geology, 44, 299-302.

BEAUVAIS, A. \& COLIN, F. (1993) Formation and transformation processes of iron duricrust systems in tropical humid environment. Chem. Geol., 106, 77-101.

BEAUVAIS, A., RUFFET, G., HÉNOCQUE, O. \& COLIN, F. (2008) Chemical and physical erosion rhythms of the West African Cenozoic morphogenesis: The 39Ar-40Ar dating of supergene K-Mn oxides. J. Geophys. Res., 113, F04007.

BEAUVAIS, A. \& CHARDON, D. (2013) Modes, tempo and spatial variability of Cenozoic cratonic denudation: The West African example. Geochem. Geophys. Geosyst., 14, 15901608. 
BENKHELIL, J. (1989) The origin and evolution of the Cretaceous Benue Trough (Nigeria). $J$. Afr. Earth Sci., 8, 251-282.

BISHOP, P. (1995) Drainage rearrangement by river capture, beheading and diversion. Prog. Phys. Geogr., 19, 449-473.

BISHOP, P. (2007) Long-term landscape evolution: linking tectonics and surface processes. Earth Surf. Proc. Land., 32, 329-365.

BONNET N.J., BEAUVAIS, A., ARNAUD, N., CHARDON, D. \& JAYANANDA, M. (2014) First ${ }^{40} \mathrm{Ar} /{ }^{39} \mathrm{Ar}$ dating of intense late Palaeogene lateritic weathering in Peninsular India. Earth Planet. Sci. Letters, 386, 126-137.

BONNET N.J., BEAUVAIS, A., ARNAUD, N., CHARDON, D. \& JAYANANDA, M. (2016) Cenozoic lateritic weathering and erosion history of Peninsular India from ${ }^{40} \mathrm{Ar} /{ }^{39} \mathrm{Ar}$ dating of supergene K-Mn oxides. Chem. Geol., 446, 33-53.

BOULANGÉ, B. \& ESCHENBRENNER, V. (1971) Note sur la présence de cuirasses témoins des niveaux bauxitiques et intermédiaires, plateau de Jos Nigéria. Bull. Ass. Sénég. Quatern. Ouest Afr., 31, 83-92.

BOULANGÉ, B., SIGOLO, J.B. \& DELVIGNE, J. (1973) Descriptions morphoscopiques, géochimiques et minéralogiques des faciès cuirassés des principaux niveaux géomorphologiques de Côte d'Ivoire. Cah. ORSTOM, sér. Géol., 5, 59-81.

BOULANGÉ, B. (1984) Les formations bauxitiques latéritiques de Côte d'Ivoire; les faciès, leur transformation, leur distribution et l'évolution du modelé. ORSTOM, Bondy, France.

BOULANGÉ, B. \& MILLOT, G. (1988) La distribution des bauxites sur le craton ouest-africain. Sci. Géol. Bull., 41, 113-123. 
BOWDEN, D.J. (1987) On the composition and fabric of the footslop laterites (duricrusts) of the Sierra Leone, West Africa, and their geomorphological significance. Z. Geomorphol. Suppl., 64, 39-53.

BRADLEY, D.C. (2008) Passive margins through earth history. Earth-Sci. Rev., 91, 1-26.

BROWNFIELD, M.E. \& CHARPENTIER, R.R. (2006) Geology and total petroleum systems of the Gulf of Guinea Province of West Africa. U.S. Geol. Surv. Bulletin, 2207-C.

BURBANK, D.W. (1992) Causes of recent Himalayan uplift deduced from deposited patterns in the Ganges basin. Nature, 357, 680-683.

BURKE, K. (1976) The chad basin: An active intra-continental basin. Tectonophysics, 36, 197206.

BURKE, K. (1996) The African Plate. S. Afr. J. Geol., 99, 339-409.

BURKE, K., MACGREGOR, D.S. \& CAMERON, N.R. (2003) Africa's petroleum systems; four tectonic 'aces' in the past 600 million years. In: Petroleum Geology of Africa: New Themes and Developing Technologies. (Ed. by T. J. Arthur, D. S. MacGregor \& N. R. Cameron), Geol. Soc. London Spec. Publ., 207, 21-60.

CAMPANILE, D., NAMBIAR, C.G., BISHOP, P., WIDDOWSON, M. \& BROWN, R. (2008) Sedimentation record in the Konkan-Kerala Basin: implications for the evolution of the Western Ghats and the Western Indian passive margin. Basin Res., 20, 3-22.

CHARDON, D., ROUBY, D., ROBIN, C., CALVES, G., GRIMAUD, J.L., GUILLOCHEAU, F., BEAUVAIS, A. \& BRAUN, J. (2013) Source to sink study of non-cylindrical rifted passive margins: the case of the Gulf of Guinea. Geophys. Res. Abstr., EGU2013-5223-1.

CHARDON, D., GRIMAUD, J.-L., Rouby, D., BEAUVAIS, A. \& CHRISTOPHOUL, F. (2016) Stabilization of large drainage basins over geological time scales: Cenozoic West Africa, hot spot swell growth, and the Niger River. Geochem. Geophys. Geosyst., 17, 1164-1181. 
579 CLIFT, P.D. (2010) Enhanced global continental erosion and exhumation driven by Oligo$580 \quad$ Miocene climate change. Geophys. Res. Lett., 37, L09402.

581 DE CAPRONA, G.C. (1992) The continental margin of western Côte d'Ivoire: Structural 582 framework inherited from intra-continental shearing. $\mathrm{PhD}$ Thesis. University of $583 \quad$ Gothenburg. Gothenburg, Sweden.

584 DOUST, H. \& OMATSOLA, E. (1990) Niger Delta. In: Divergent/passive Margin Basins (Ed. 585 by J. D. Edwards \& P. A. Santogrossi), AAPG Memoir, 48, 239-248.

DUROTOYE, B. (1989) Quaternary sediments in Nigeria. In: Geology of Nigeria, 2nd edition

(Ed. by C. A. Kogbe), 431-444. Rock View International, Paris, France.

EMERY, K.O., UCHUPI, E., PHILLIPS, J., BOWIN, C.O., \& MASCLE, J. (1975) Continental margin of Western Africa: Angola to Sierra Leone. Am. Assoc. Pet. Geol. Bull., 59, 22092265.

ESCHENBRENNER, R. \& GRANDIN, G. (1970) La séquence de cuirasses et ses différenciations entre Agnibiléfrou et Diébougou (Haute-Volta). Cah. ORSTOM, Sér. Géol., 2, 205-246.

FEYBESSE, J.-L., BILLA, M., GUERROT, C., DUGUEY, E., LESCUYER, J.-L., MILESI, J.-P. \& BOUCHOT, V. (2006) The paleoproterozoic Ghanaian province: Geodynamic model and ore controls, including regional stress modeling. Precambrian Res., 149, 149-196.

FÖLSTER, H. (1969) Late Quaternary erosion phases in SW Nigeria. Bull. Ass. Sénég. Quatern. Ouest Afr., 21, 29-35.

FRITSCH, P. (1978) Chronologie relative des formations cuirassées et analyse géographique des facteurs de cuirassement au Cameroun. Trav. Doc. CEGET, 33, 114-132.

GILCHRIST, A.R. \& SUMMERFIELD, M.A. (1990) Differential denudation and flexural isostasy in formation of rifted-margin upwarps. Nature, 346, 739-742. 
603

604

605

606

607

608

609

610

611

612

613

614

615

616

617

618

619

620

621

622

623

624

GRANDIN, G. \& HAYWARD, D.F. (1975) Aplanissements cuirassés de la péninsule de Freetown (Sierra-Léone). Cah. ORSTOM, sér. Géol., 7, 11-16.

GRANDIN, G. (1976) Aplanissements cuirassés et enrichissement des gisements de manganèse dans quelques régions d'Afrique de l'Ouest. ORSTOM, Paris, France.

GREIGERT, J. (1966) Description des formations crétacées et tertiaires du Bassin des Iullemmeden (Afrique occidentale). Editions BRGM, Paris, France.

GRIMAUD, J.-L. (2014) Dynamique long-terme de l'érosion en contexte cratonique: l'Afrique de l'Ouest depuis l'Eocène. PhD Thesis, Toulouse University, Toulouse, France.

GRIMAUD, J.-L., CHARDON, D. \& BEAUVAIS, A. (2014) Very long-term incision dynamics of big rivers. Earth Planet. Sci. Lett., 405, 74-84.

GRIMAUD, J.-L., CHARDON, D., METELKA, V., BEAUVAIS, A. \& BAMBA, O. (2015) Neogene cratonic erosion fluxes and landform evolution processes from regional regolith mapping (Burkina Faso, West Africa). Geomorphology, 241, 315-330.

GUILLOCHEAU, F., ROUBY, D., ROBIN, C., HELM, C., ROLLAND, N., LE CARLIER DE VESLUD, C. \& BRAUN, J. (2012) Quantification and causes of the terrigeneous sediment budget at the scale of a continental margin: a new method applied to the Namibia-South Africa margin. Basin Res., 24, 3-30.

GUILLOCHEAU, F., CHELALOU, R., LINOL, B., DAUTEUIL, O., ROBIN, C., MVONDO, F., CALLEC, Y. \& COLIN, J. P. (2015) Cenozoic landscape evolution in and around the Congo Basin: constraints from sediments and planation surfaces. In: Geology and Resource Potential of the Congo Basin (Ed. by M. J. de Wit, F. Guillocheau \& M. C. J. de Wit), Regional Geology Reviews, 271-313. Springer Berlin Heidelberg, Berlin Germany. 
HAACK, R.C., SUNDARARAMAN, P., DIEDJOMAHOR, J.O., XIAO, H., GANT, N.J., MAY, E.D. \& KELSCH, K. (2000) Niger Delta petroleum systems, Nigeria. In: Petroleum systems of South Atlantic margins (Ed. by M. R. Mello \& B. J. Katz), AAPG Memoir, 48, 213-231.

HELM, C. (2009) Quantification des flux sédimentaires anciens à l'échelle d'un continent : le cas de l’Afrique au Méso-Cénozoïque. PhD Thesis. Rennes University, Rennes, France.

JERMANNAUD, P., ROUBY, D., ROBIN, C., NALPAS, T., GUILLOCHEAU, F. \& RAILLARD, S. (2010) Plio-Pleistocene sequence stratigraphic architecture of the eastern Niger Delta: A record of eustasy and aridification of Africa. Mar. Pet. Geol., 27, 810-821.

JEROLMACK, D.J. \& PAOLA, C. (2010) Shredding of environmental signals by sediment transport. Geophys. Res. Lett., 37, L19401.

KING, L.C. (1962) The Morphology of the Earth. Oliver and Boyd, Edinburgh, UK.

LABAILS, C., OLIVET, J.-L., ASLANIAN, D. \& ROEST, W.R. (2010) An alternative early opening scenario for the Central Atlantic Ocean. Earth Planet. Sci. Lett., 297, 355-368.

LAVIER, L.L., STECKLER, M.S. \& BRIGAUD, F. (2001) Climatic and tectonic controls on the Cenozoic evolution of the West African margin. Mar. Geol., 178, 63-80.

LETURMY, P., LUCAZEAU, F., \& BRIGAUD, F. (2003) Dynamic interactions between the gulf of Guinea passive margin and the Congo River drainage basin: 1. Morphology and mass balance. J. Geophys. Res.: Solid Earth, 108, 2156-2202.

LINOL, B., DE WIT, M.J., GUILLOCHEAU, F., DE WIT, M.C.J., ANKA, Z. \& COLIN, J.-P. (2014) Formation and Collapse of the Kalahari Duricrust ['African Surface'] Across the Congo Basin, with Implications for Changes in Rates of Cenozoic Off-Shore Sedimentation. In: Geology and Resource Potential of the Congo Basin (Ed. by M. J. de 
Wit, F. Guillocheau \& M. C. J. de Wit), Regional Geology Reviews, 193-210. Springer Berlin Heidelberg, Berlin Germany.

MACGREGOR, D.S., ROBINSON, J. \& SPEAR, G. (2003) Play fairways of the Gulf of Guinea

MACGREGOR, D.S. (2013) Late Cretaceous-Cenozoic sediment and turbidite reservoir supply transform margin. In: Petroleum Geology of Africa: New Themes and Developing Technologies. (Ed. by T. J. Arthur, D. S. MacGregor \& N. R. Cameron), Geol. Soc. London Spec. Publ., 207, 131-150.

MALLET, J.L. (1992) Discrete smooth interpolation in geometric modelling. Computer-Aided Design, 24, 178-191.

MÉTIVIER, F. \& GAUDEMER, Y. (1999) Stability of output fluxes of large rivers in South and East Asia during the last 2 million years: implications on floodplain processes. Basin Res.,

MÉTIVIER, F., GAUDEMER, Y., TAPPONNIER, P., \& KLEIN, M., (1999) Mass accumulation rates in Asia during the Cenozoic. Geophys. J. Int., 137, 280-318.

MICHEL, P. (1973) Les bassins des fleuves Sénégal et Gambie : étude géomorphologique.

MICHEL, P. (1977a) Les modelés et dépôts du Sahara méridional et Sahel et du Sud-Ouest ORSTOM, Paris, France. africain. Rech. Géograph. Strasbourg, 5, 5-39.

668 MICHEL, P. (1977b) Recherches sur le Quaternaire en Afrique occidentale. Supp. Bull. AFEQ, 50, 143-153.

MILLOT, G. (1970) Geology of Clays. Springer Verlag, Berlin, Germany. 
670

671

672

673

674

675

676

677

678

679

680

681

682

683

684

685

686

687

688

689

690

691

MOLNAR, P. (2004) Late Cenozoic increase in accumulation rates of terrestrial sediment: How Might Climate Change Have Affected Erosion Rates? Annu. Rev. Earth Planet. Sci., 32, 67-89.

MOULIN, M., ASLANIAN, D. \& UNTERNEHR, P. (2010) A new starting point for the South and Equatorial Atlantic Ocean. Earth-Sci. Rev., 98, 1-37.

NEWILL, D. \& DOWLING, J.W.F. (1968) Laterites in West Malaysia and Northern Nigeria. Int. Conf. SMFE, Spec. Sess. on Eng. Propeties of Lateritic Soils, 2, 133-150.

PAZZAGLIA, F.J. \& GARDNER, T.W. (1994) Late Cenozoic flexural deformation of the middle U.S. Atlantic passive margin. J. Geophys. Res.: Solid Earth, 99, 12143-12157.

RADIER, H. (1959) Contribution à l'étude géologique du Soudan oriental (AOF). 2 Le bassin crétacé et tertiaire de Gao le détroit soudanais. Service de géologie et de prospection minière, Dakar, Sénégal.

REIJERS, T. (2011) Stratigraphy and sedimentology of the Niger Delta. Geologos, 17, 133-162. RIFFEL, S. B., VASCONCELOS, P. M., CARMO, I. O. \& FARLEY, K. A. (2015) Combined 40Ar/39Ar and (U-Th)/He geochronological constraints on long-term landscape evolution of the Second Paraná Plateau and its ruiniform surface features, Paraná, Brazil, Geomorphology, 233, 52-63.

ROBIN, C., GUILLOCHEAU, F., JEANNE, S., PORCHER, F. \& CALVÈS, G. (2011) Cenozoic siliciclastic fluxes evolution around Africa. Geophys. Res. Abstr., 13, EGU2011-5659.

ROGNON, P., GOURINARD, Y., BANDET, Y., KOENIGUER, J.C. \& DELTEIL-DESNEUX, F. (1983) Précisions chronologiques sur l'évolution volcanotectonique et 
géomorphologique de l'Atakor (Hoggar); apports des données radiométriques (K/Ar) et paléobotaniques (bois fossiles). Bull. Soc. Géol. Fr., 25, 973-980.

ROUBY, D., BONNET, S., GUILLOCHEAU, F., GALLAGHER, K., ROBIN, C., BIANCOTTO, F., DAUTEUIL, O. \& BRAUN, J. (2009) Sediment supply to the Orange sedimentary system over the last $150 \mathrm{My}$ : An evaluation from sedimentation/denudation balance. Mar. Pet. Geol., 26, 782-794.

ROUBY, D., BRAUN, J., ROBIN, C., DAUTEUIL, O. \& DESCHAMPS, F. (2013) Long-term stratigraphic evolution of Atlantic-type passive margins: A numerical approach of interactions between surface processes, flexural isostasy and 3D thermal subsidence. Tectonophysics, 604, 83-103.

ROUGIER, S., MISSENARD, Y., GAUTHERON, C., BARBARAND, J., ZEYEN, H., PINNA, R., LIÉGEOIS, J.-P., BONIN, B., OUABADI, A., DERDER, M.E.-M. \& DE LAMOTTE, D.F. (2013) Eocene exhumation of the Tuareg Shield (Sahara Desert, Africa). Geology, 41, 615-618.

SADLER, P.M. (1981) Sediment accumulation rates and the completeness of stratigraphic sections. J. Geol., 89, 569-584.

SÉRANNE, M. (1999) Early Oligocene stratigraphic turnover on the west Africa continental margin: a signature of the Tertiary greenhouse-to-icehouse transition? Terra Nova, 11, $135-140$.

SÉRANNE, M. \& NZÉ ABEIGNE, C.-R. (1999) Oligocene to Holocene sediment drifts and bottom currents on the slope of Gabon continental margin (west Africa): Consequences for sedimentation and southeast Atlantic upwelling. Sed. Geol., 128, 179-199.

SIMOES, M., BRAUN, J. \& BONNET, S. (2010) Continental-scale erosion and transport laws: A new approach to quantitatively investigate macroscale landscapes and associated 
sediment fluxes over the geological past. Geochem. Geophys. Geosyst., 11, Q09001, doi:10.1029/2010GC003121

718

719

720

721

722

723

724

725

726

727

728

729

730

731

732

733

734

735

736

737

TARDY, Y. \& ROQUIN, C. (1998) Dérive des continents, paléoclimats et altérations tropicales. BRGM, Orléans, France.

TEEUW, R.M. (2002) Regolith and diamond deposits around Tortiya, Ivory Coast, West Africa. CATENA, 49, 111-127.

THOMAS, M.F. (1980) Timescales of landform development on tropical shields; a study from Sierra Leone. In: Timescales in Geomorphology (Ed. by R.A Cullingford, D.A. Davidson \& J. Lewin), 333-354. John Wiley \& Sons, Chichester, UK.

THOMAS, M.F. (1994) Geomorphology in the Tropics: A Study of Weathering and Denudation in Low Latitudes. John Wiley \& Sons, New York, US.

VALETON, I. (1991) Bauxites and associated terrestrial sediments in Nigeria and their position in the Bauxite belts of Africa. J. Afr. Earth Sci., 12, 297-310.

VASCONCELOS, P.M. \& CONROY, M. (2003) Geochronology of weathering and landscape evolution, Dugald River valley, NW Queensland, Australia. Geochim. Cosmochim. Acta, 67, 2913-2930. doi:10.1016/S0016-7037(02)0137

VASCONCELOS, P.M., BRIMHALL, G.H., BECKER, T.A. \& RENNE, P.R. (1994a) ${ }^{40} \mathrm{Ar} /{ }^{39} \mathrm{Ar}$ analysis of supergene jarosite and alunite: Implications to the paleoweathering history of the western USA and West Africa. Geochim. Cosmochim. Acta, 58, 401-420.

VASCONCELOS, P.M., RENNE, P.R., BRIMHALL, G.H. \& BECKER, T.A. (1994b) Direct dating of weathering phenomena by ${ }^{40} \mathrm{Ar} /{ }^{39} \mathrm{Ar}$ and $\mathrm{K}-\mathrm{Ar}$ analysis of supergene $\mathrm{K}-\mathrm{Mn}$ oxides. Geochim. Cosmochim. Acta, 58, 1635-1665. doi:10.1016/0016-7037(94)9056 
VILLENEUVE, M. (2005), Paleozoic basins in West Africa and the Mauritanide thrust belt. J. Afr. Earth Sci., 43(1-3), 166-195.

WALFORD, H.L. \& WHITE, N.J. (2005) Constraining uplift and denudation of west African continental margin by inversion of stacking velocity data. J. Geophys. Res., 110, B04403.

WINDOM, H.L. (1975) Eolian contributions to marine sediments. J. Sediment. Res., 45, 520-529. YE, J., CHARDON, D., ROUBY, D., GUILLOCHEAU, F., DALL’ASTA, M., FERRY, J.N. \& BROUCKE, O. (2017) Paleogeographic and structural evolution of northwestern Africa and its Atlantic margins since the Early Mesozoic. Geosphere, 13, in press. doi:10.1130/GES01426.1

ZACHOS, J., PAGANI, M., SLOAN, L., THOMAS, E. \& BILLUPS, K. (2001) Trends, Rhythms, and Aberrations in Global Climate 65 Ma to Present. Science, 292, 686-693.

\section{FIGURES CAPTIONS}

Fig. 1: Schematic representation of a source-to-sink system with the riverine transport of sediment from the continent to the ocean. The figure focuses on the clastic flux and does not represent the solute load.

Fig. 2: Map showing the main geologic and morphologic features of Sub-Saharan West Africa modified after Grimaud et al. (2014). The offshore accumulation map of Emery et al. (1975) does not cover the Central Atlantic margin of Africa (i.e. offshore Senegal-Mauritania basin). 
760 of lateritic paleo-landsurfaces and associated regoliths (weathering mantles and associated 761 duricrusts) in the landscape. [b] Comparison of the ages acquired in the lateritic mantles of

762 Tambao and Syama, (Fig. 2) [after Beauvais et al. (2008) (light grey dots) and Vasconcelos et al. 763 (1994a) (dark grey dots) respectively] to the oceanic $\delta^{18} \mathrm{O}$ variation (\%o) on benthic foraminifera 764 tests recording global temperature variations (Zachos et al., 2001). Only the ages with an 765 uncertainty lower than 5 Myr have been reported in Syama (dark grey dots).

767 Fig. 4: Interpretation of paleo-landsurface distribution after our field work in several type768 locations in West Africa (see location on Fig. 2). Google-Earth view and interpretation of paleo769 surface distribution: [a] over the Precambrian basement, South of Tambao (Burkina Faso); [b] 770 over the Precambrian basement near the Manding Mounts (Mahadougou, Mali); [c] in the Niger

771 inland delta, North of Bamako (Ségou, Mali) where bauxitic remnants are found 60 m above the

772 Niger River; [d] in the Iullemmeden basin (North of Niamey, Niger) where the deposits of the 773 “Continental Terminal”, capped with the Intermediate surface, have been incised by the Niger 774 River system. The color code of relict landforms interpretations is similar to Fig. 3.

776 Fig. 5: [a] Map of the 2900 data points used to build the 3D surfaces. [b] Schematic distribution 777 of relict landforms and reconstructed surface geometries. [c] Schematic distribution of data points 778 constraining the construction of surface geometries in alluvial plains and sedimentary basins. B 779 points correspond to bedrock massifs summit (referred as “inselbergs”), C points to the top of

780 Early-Mid Eocene carbonates and D points to S1 weathering profile remnants. B points

781 inselbergs are often associated with eroded S1 weathering profiles. B points therefore constrain 
S1 minimum elevation. C points are time equivalents of S1 bauxite retrieved from well log in

783 sedimentary basins. We used them as depth of S1 below the topography in these basins. D points

784 constrain locally the elevation of S1 paleo-surface, which have been eroded, on the basis that a

785 bauxitic weathering profile cannot exceed the maximum depth of $120 \mathrm{~m}$ (estimates based on

786 electric profiles; Boulangé et al., 1973).

788 Fig. 6: [a] Simplified map of the 4 selected drainage groups (bounded by black lines):

789 Senegambia drainage, Short Atlantic drainages, Long Atlantic drainages and the Niger

790 catchment. The modern limits of the Cenozoic onshore sedimentary basins (Senegal-Mauritania

791 [S.M.], Iullemmeden [Iu.] and Togo-Benin [T.B] basins) (red dashed lines) and main topographic

792 massifs (Tagant [Tag.], Hoggar [Hog.], Guinean Rise [G.R.] Jos plateau [Jos] and Adamaoua

793 massif [Ad.]) (grey areas) are also shown. Denudations maps of the 45-24 Ma [b], 24-11 Ma [c]

794 and 11-0 Ma intervals [d]. Successive divides (black dashed lines) are drawn after Chardon et al.

795 (2016). Where the position of these divides was less constrained, the uncertainty area is

796 represented between two dashed lines.

798 Fig. 7: Cenozoic denudation map and associated exported volumes. [a] Map of total denudation

799 depth at the scale of Sub-Saharan West Africa since the abandonment of S1. Clastic export rates

800 are shown by drainage groups (i.e. Senegambia drainage [b], Short Atlantic drainages [c], Long

801 Atlantic drainages [d] and the Niger catchment [e]). The eastern swells are separated from the

802 rest of the study area by the black dashed line. 
804 Fig. 8: Regional cross-sections of lateritic relict landforms distribution and contemporary

805 sedimentary deposits (see Fig. 5 for location). [a] Cross-section through the Hoggar massif and

806 Iullemmeden basin. [b] Cross section through the Benue trough and onshore Niger delta (geology

807 after Benkhelil, 1989; volcanic accumulation in the Hoggar massif after Rognon et al., 1983).

808 The red, purple and green dashed lines represent large-scale interpolations of the S1, S2 and S3

809 surfaces, respectively.

811 Fig. 9: Offshore accumulation histories. [a] 3D topography and bathymetry showing the location 812 of the cross sections used in the study. [b] Example of cross-section for the Niger delta (after 813 Haack et al., 2000). [c] Example of cross-section for the sediment accumulation offshore Ivory 814 Coast (after Helm, 2009; see Supporting Information). [d] Evolution of volumetric accumulation 815 rates in the Niger delta (after Haack et al., 2000 and Robin et al., 2011). [e] Evolution of 816 volumetric accumulation rates in the Niger delta after time re-sampling in order to compare to the 817 continental denudation chronology (i.e. 45-23, 23-11.6 and 11.6-0 Ma; see Table 2). [f] Evolution 818 of volumetric accumulation rates on the African margin of the Equatorial Atlantic (modified after 819 Helm 2009). See methods section and Supporting Information for details. Error bars include a 820 Monte Carlo estimation of uncertainties related to sections interpolation, as well as non-clastic 821 material (i.e. carbonates and volcanics) and porosity corrections. 


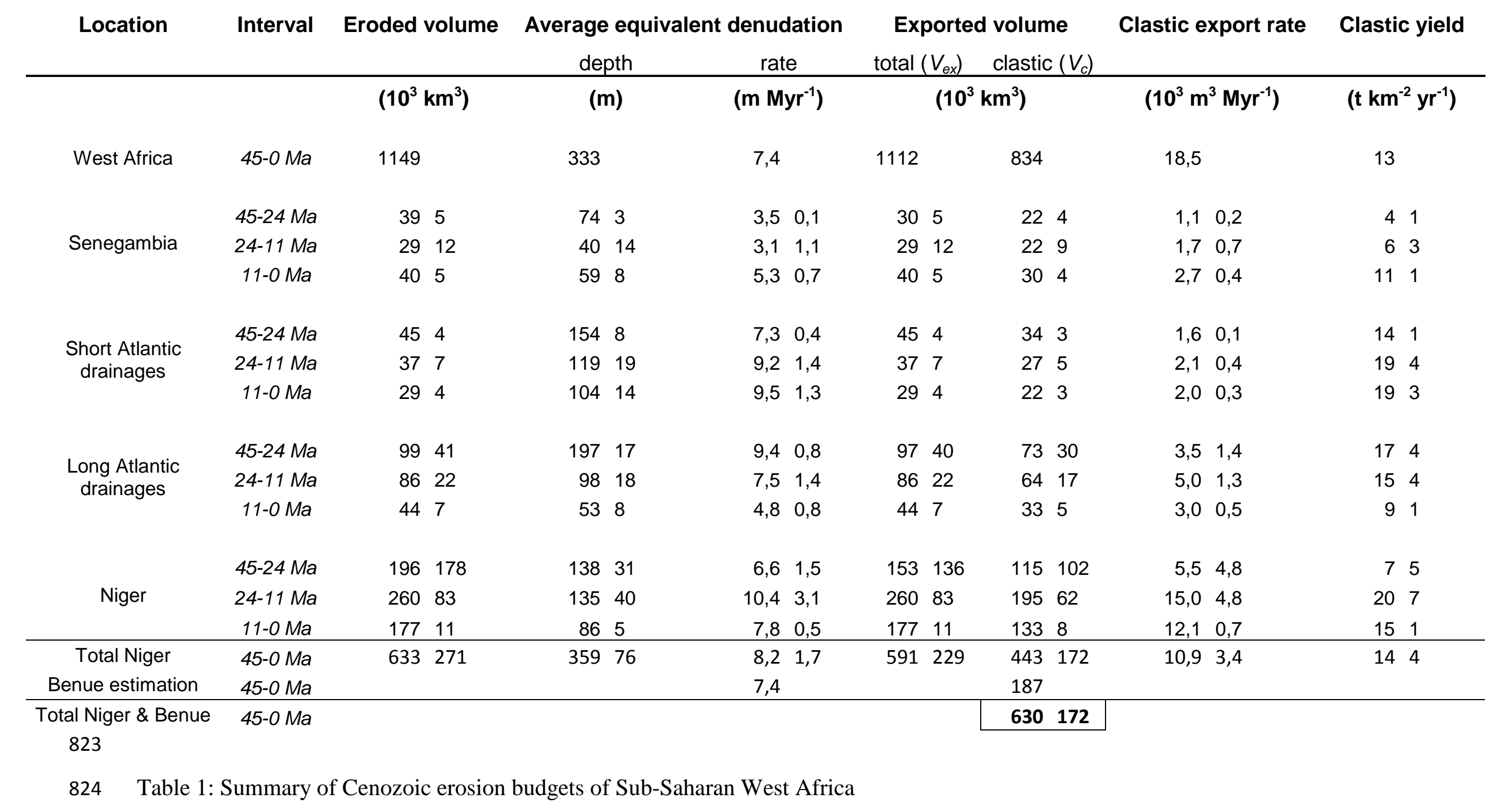


825

\begin{tabular}{ccc} 
& $\begin{array}{c}\text { Interval } \\
(\mathrm{Ma})\end{array}$ & $\begin{array}{c}\text { Accumulated volume } \\
\left(10^{3} \mathrm{~km}^{3}\right)\end{array}$ \\
& $1.8-0$ & $46.8 \pm 6.3$ \\
S3 - modern & $5.3-1.8$ & $142.3 \pm 19.9$ \\
& $11.6-5.3$ & $127.7 \pm 17.8$ \\
\hline \multirow{2}{*}{ S2 - S3 } & $16-11.5$ & $85.4 \pm 11.9$ \\
& $23-11.5$ & $61 \pm 8.5$ \\
\hline \multirow{2}{*}{ S1-S2 } & $33.9-23$ & $69.8 \pm 10.4$ \\
& $45-33.9$ & $44.4 \pm 15.7$ \\
\hline & $55.8-33.9$ & $87.6 \pm 30.9$ \\
& Total 45-0 & $577.4 \pm 90.5$
\end{tabular}

826

827 Table 2: Summary of Cenozoic clastic volumes accumulated in the Niger delta.

828 


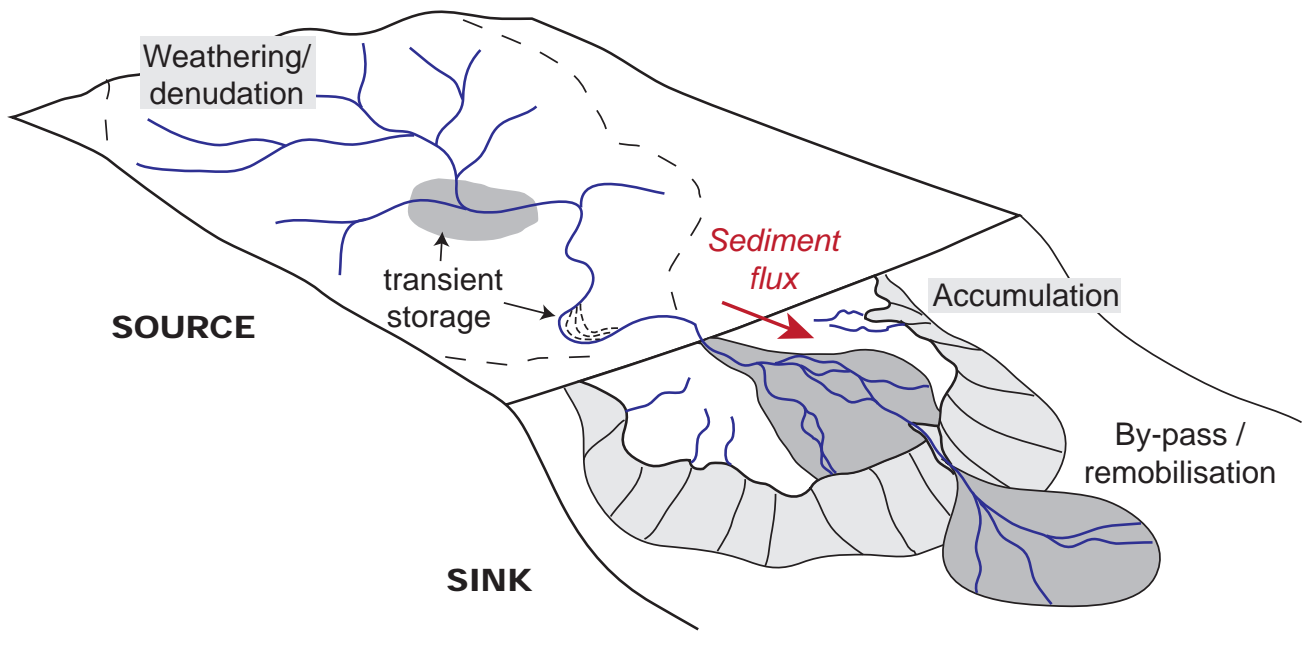

Grimaud et al., Fig. 1 


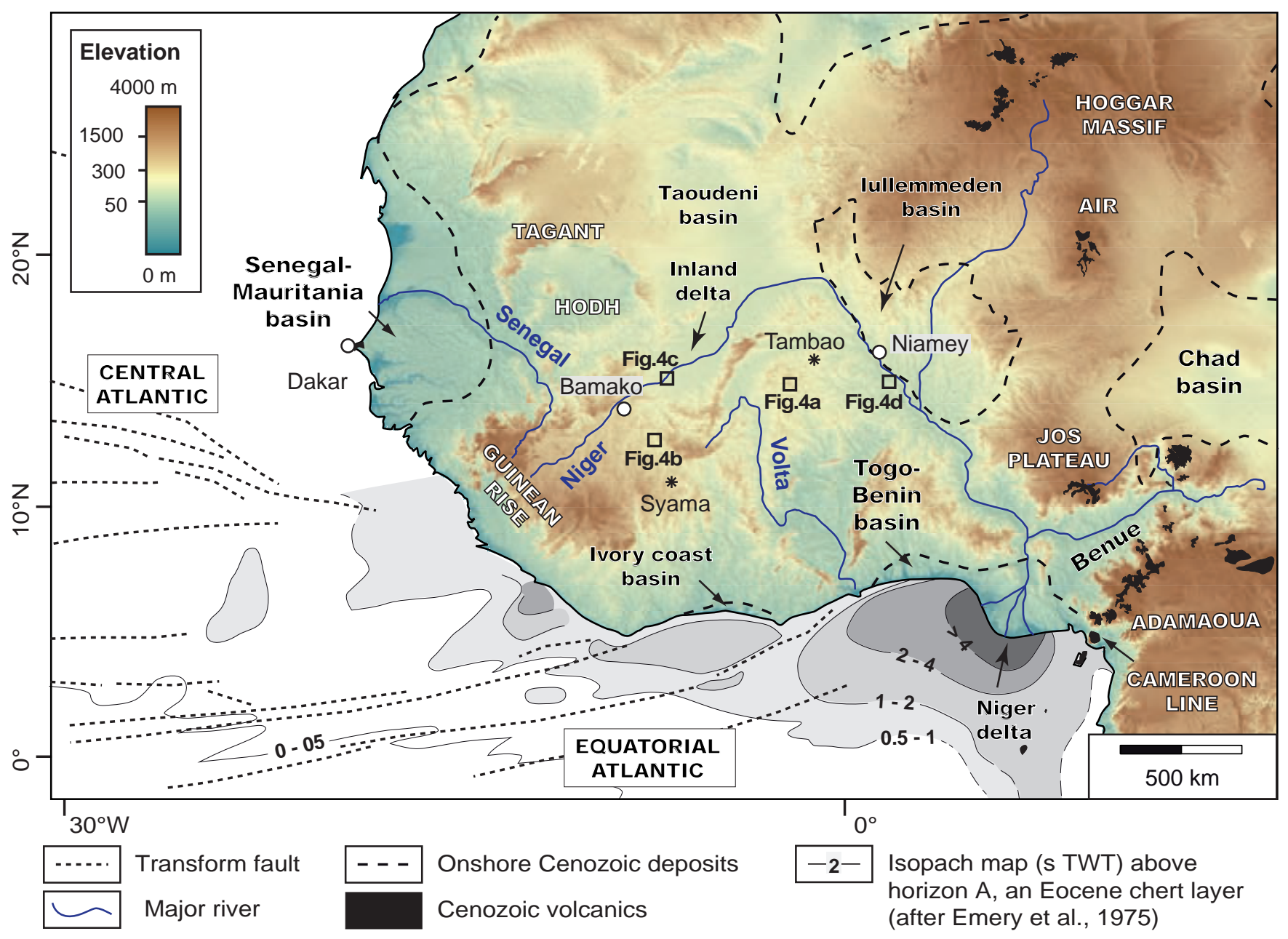

Grimaud et al., Fig. 2 


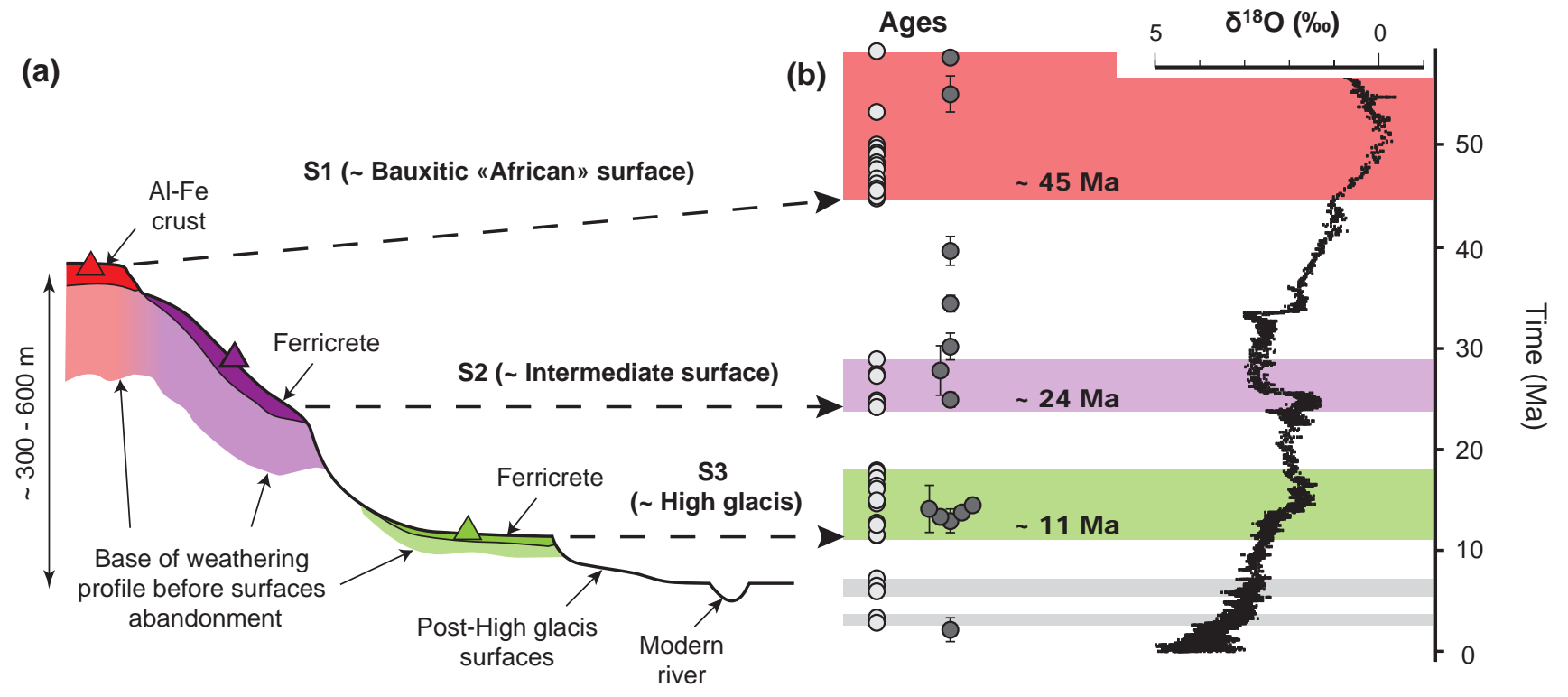

Grimaud et al., Fig. 3 

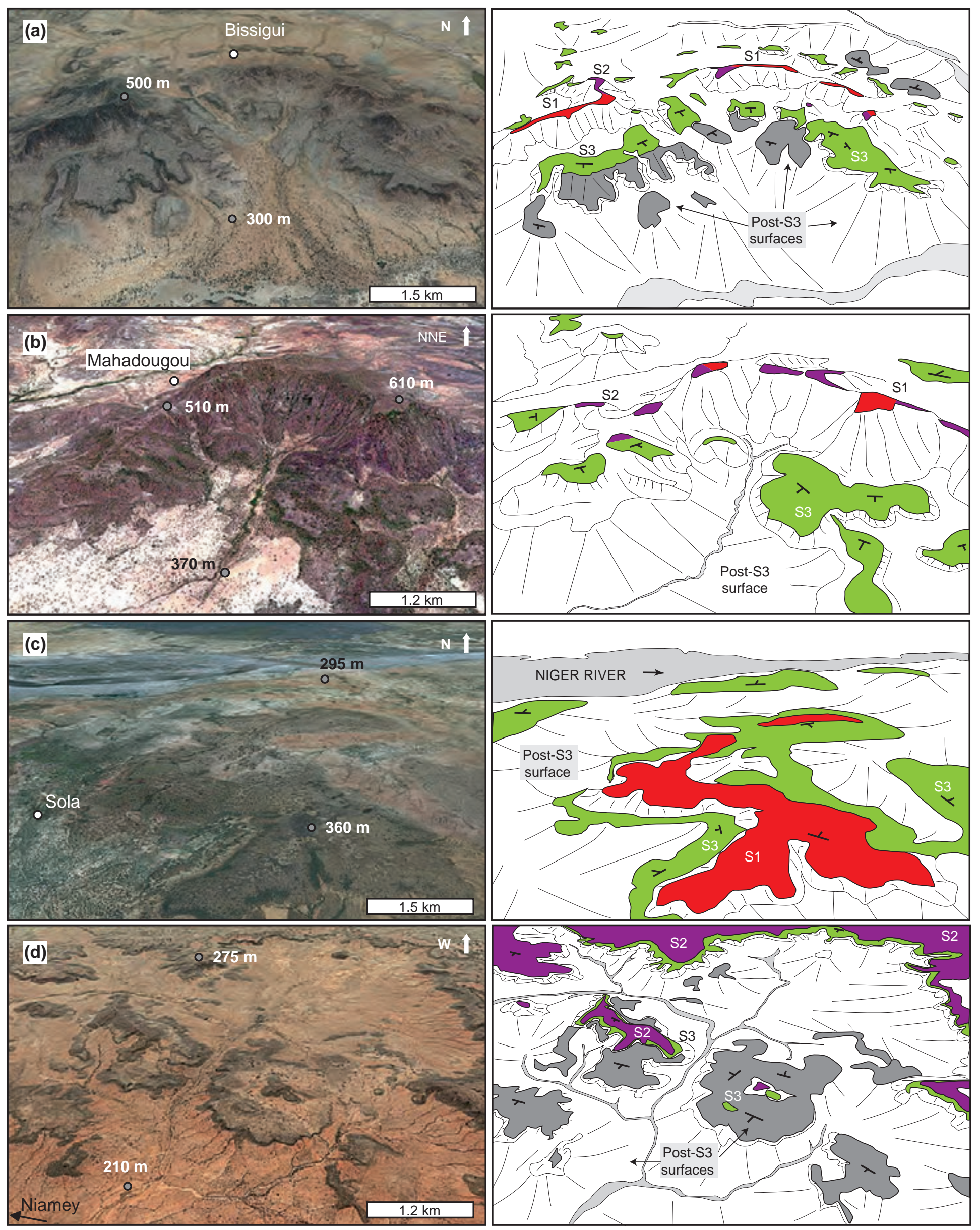

Grimaud et al., Fig. 4 


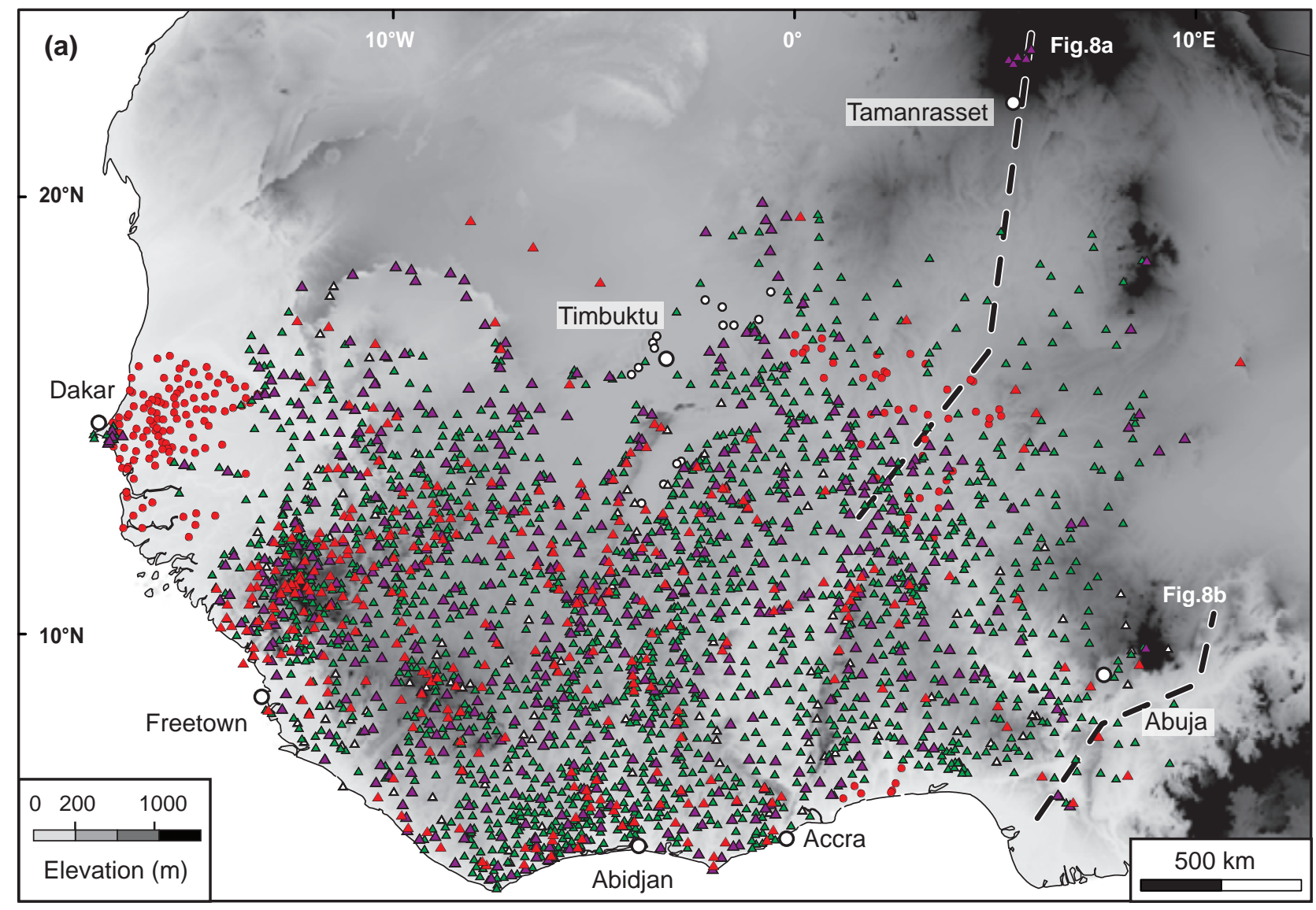

(b) Construction of surface geometries

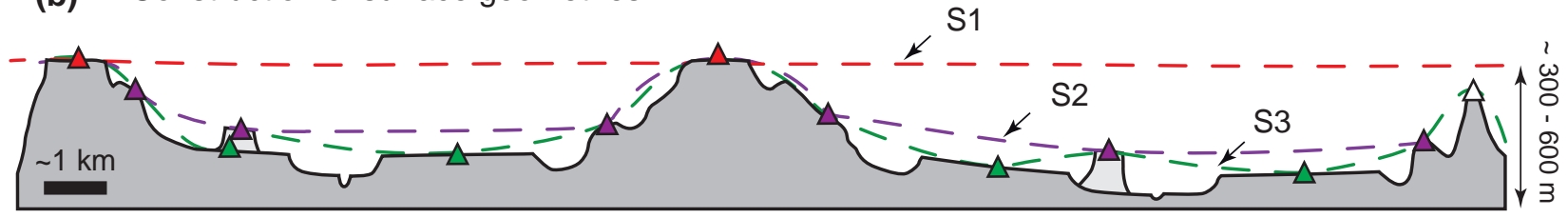

(c) Constraints in inland alluvial plains and sedimentary basins

RECONSTRUCTED

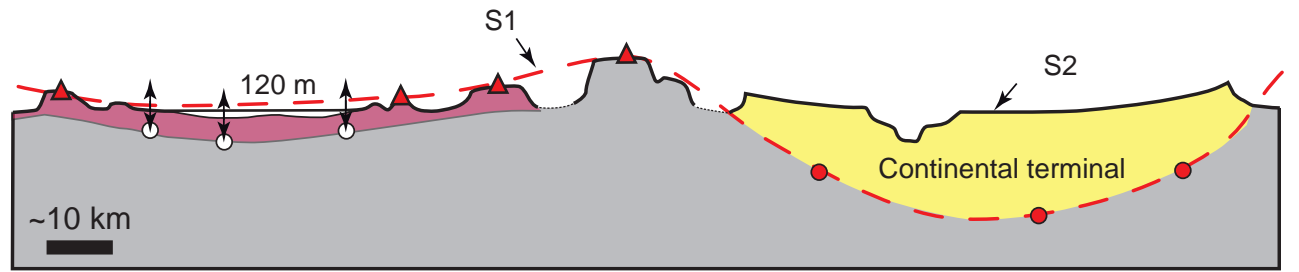

PALEOSURFACES

$-\quad$ S1 surface

$-\quad$ S2 surface

$-\quad$ s3 surface

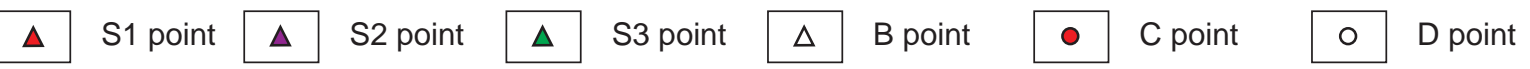

Grimaud et al., Fig. 5 

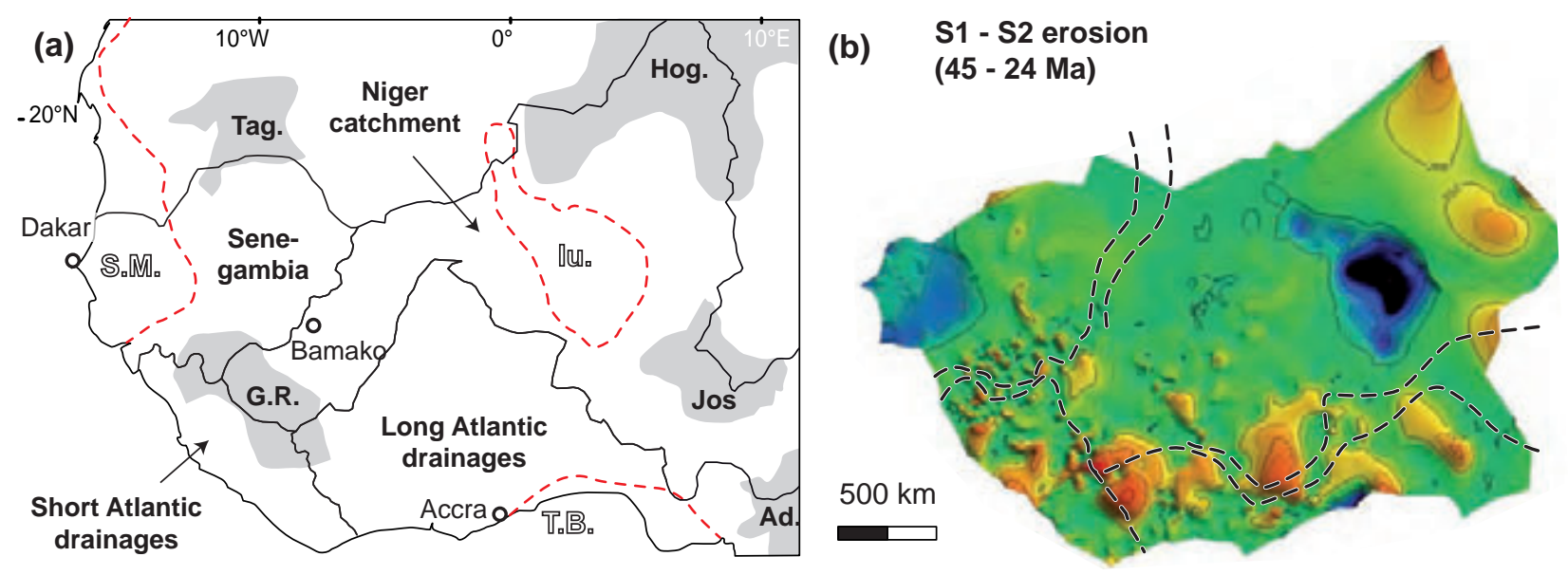

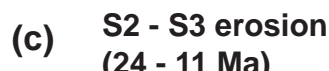
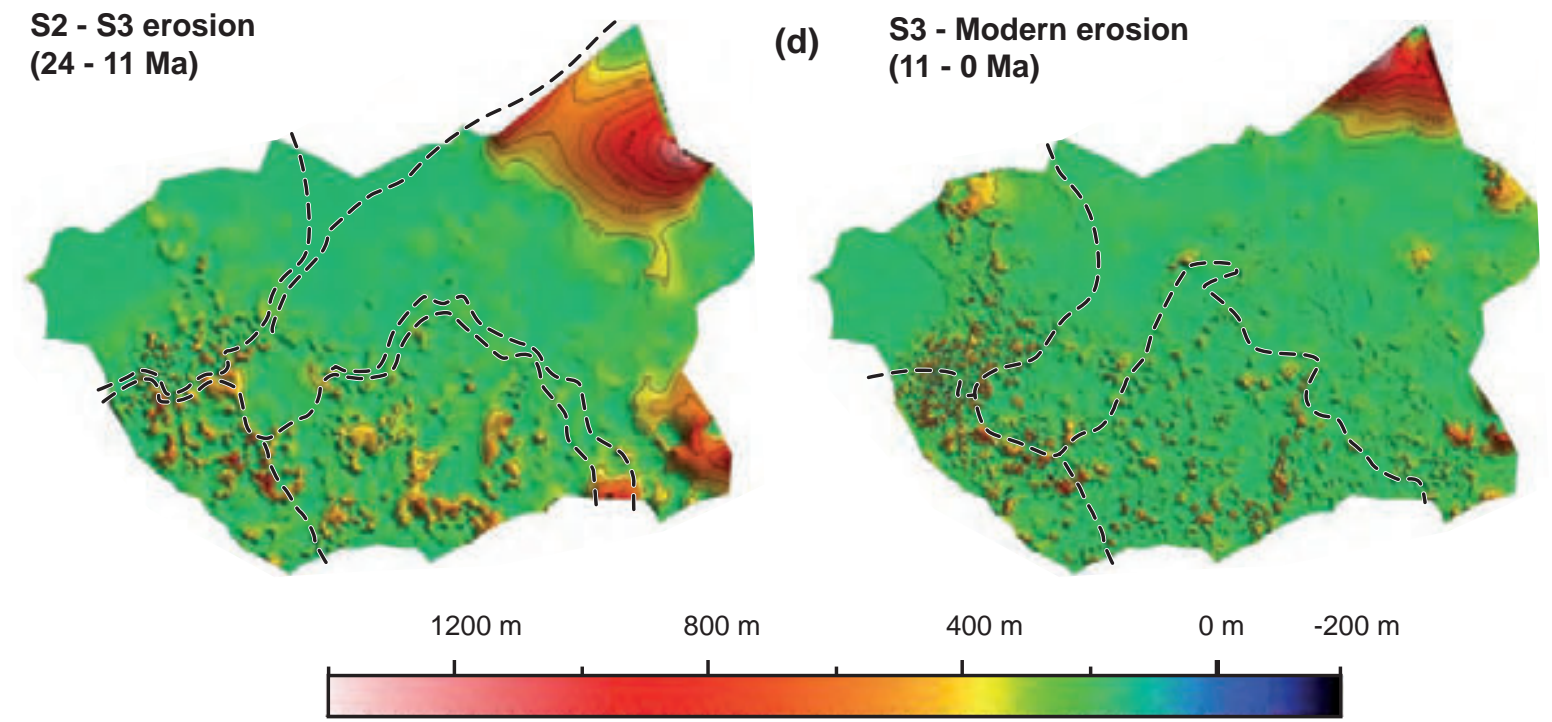

Denudation depth

Grimaud et al., Fig. 6 


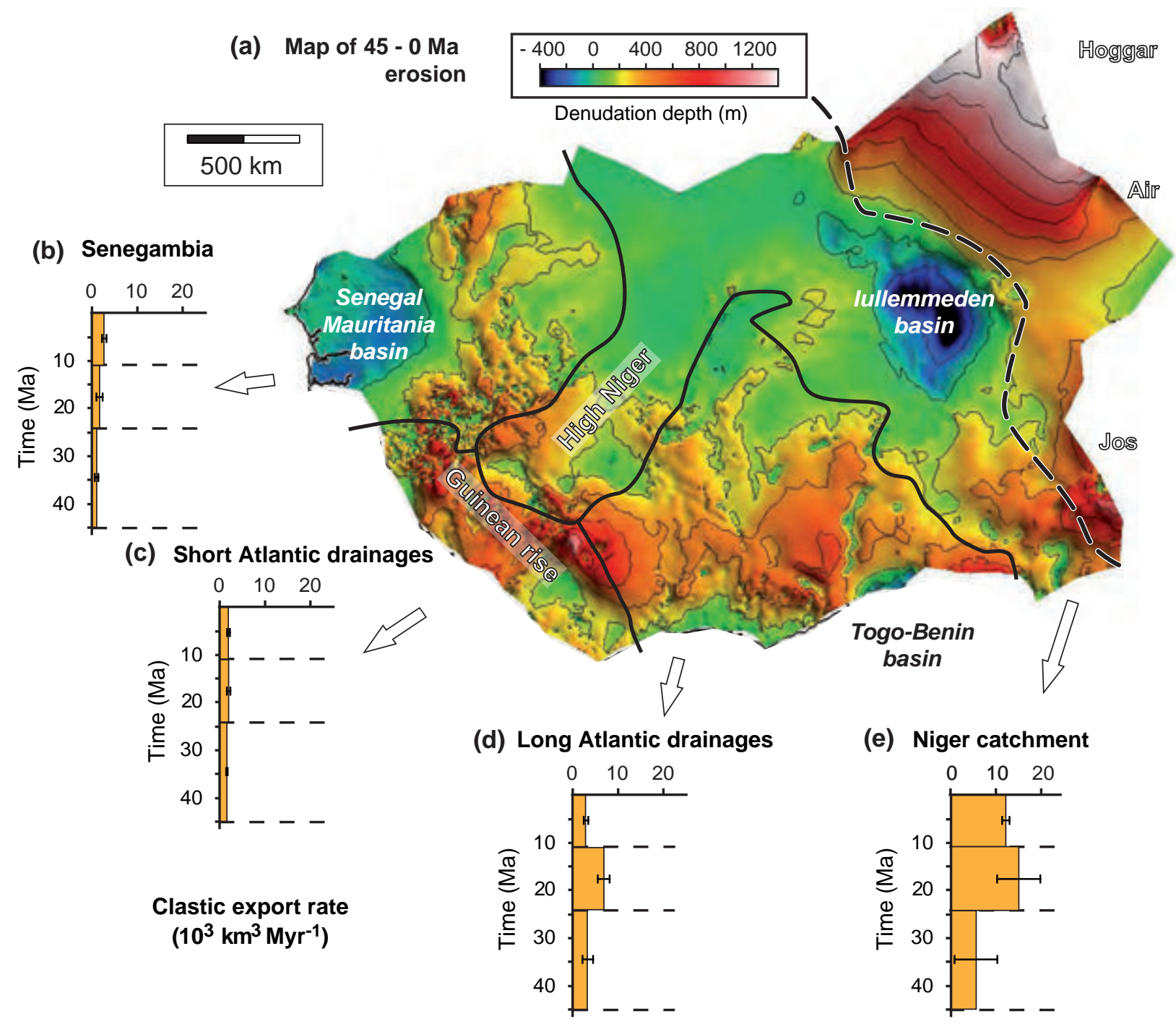

Grimaud et al., Fig. 7 
(a) NNE

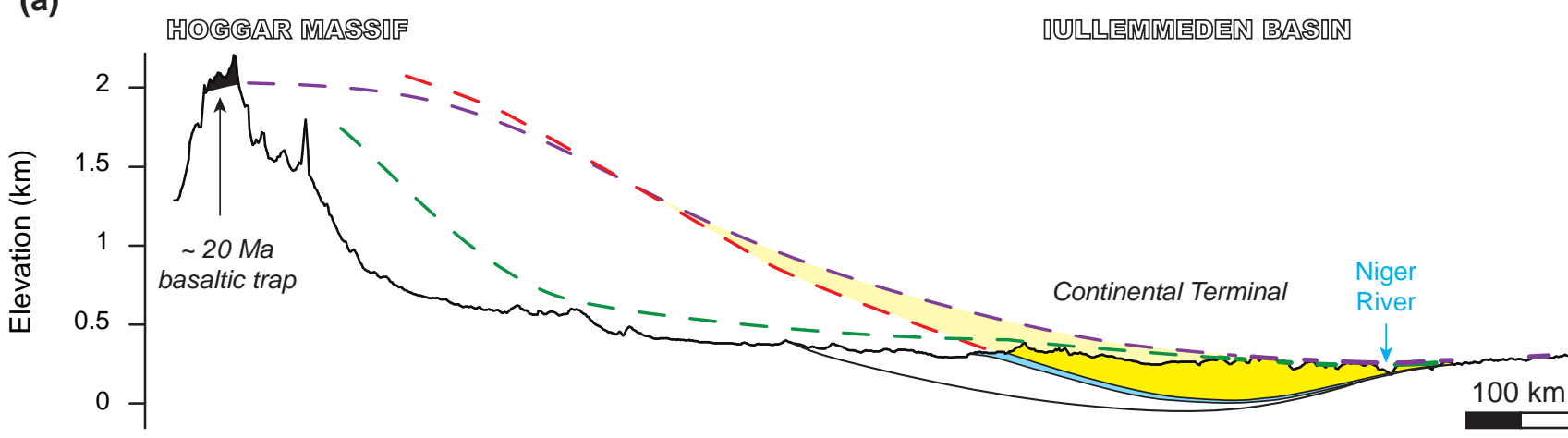

(b) WSW

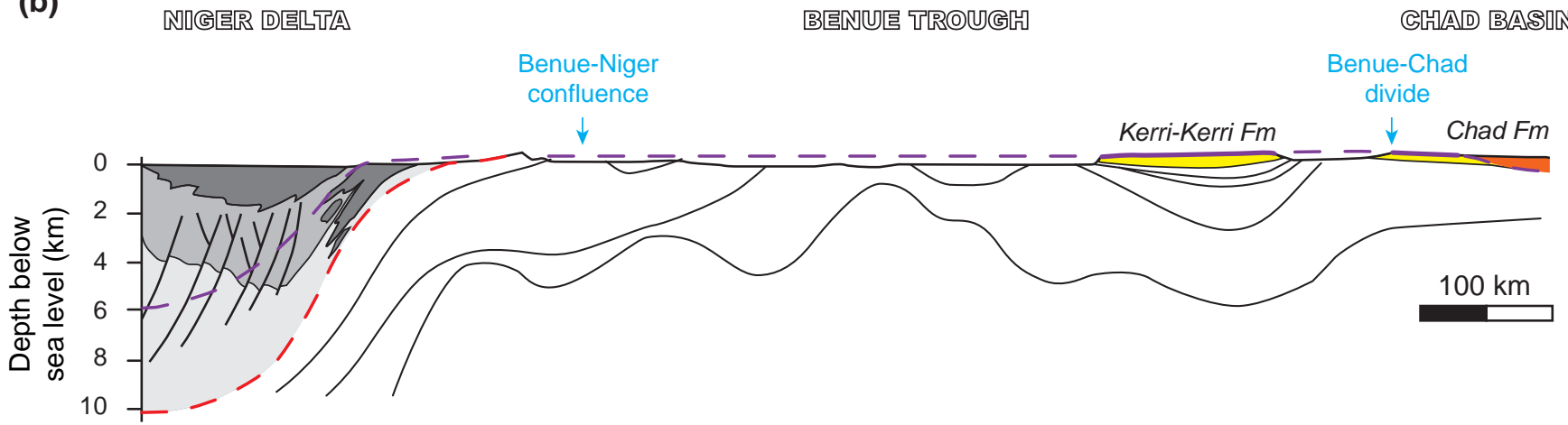

Relict landforms and paleosurfaces

\begin{tabular}{|c|c|c|c|}
\hline 一 & S1 relict & -- & $\mathrm{S} 1(\sim 45 \mathrm{Ma})$ \\
\hline - & S2 relict & -- & $\mathrm{S} 2(\sim 24 \mathrm{Ma})$ \\
\hline$\longrightarrow$ & S3 relict & -- & $\mathrm{S} 3(\sim 11 \mathrm{Ma})$ \\
\hline
\end{tabular}

\section{Depositional features}

\begin{tabular}{|c|c|}
\hline Neogene lacustrine deposits & Mid-Eocene carbonates ( $60-45 \mathrm{Ma})$ \\
\hline Onshore Paleogene deposits & Cenozoic delta deposits \\
\hline Eroded Paleogene deposits & Mesozoic strata \\
\hline
\end{tabular}

Grimaud et al., Fig. 8 


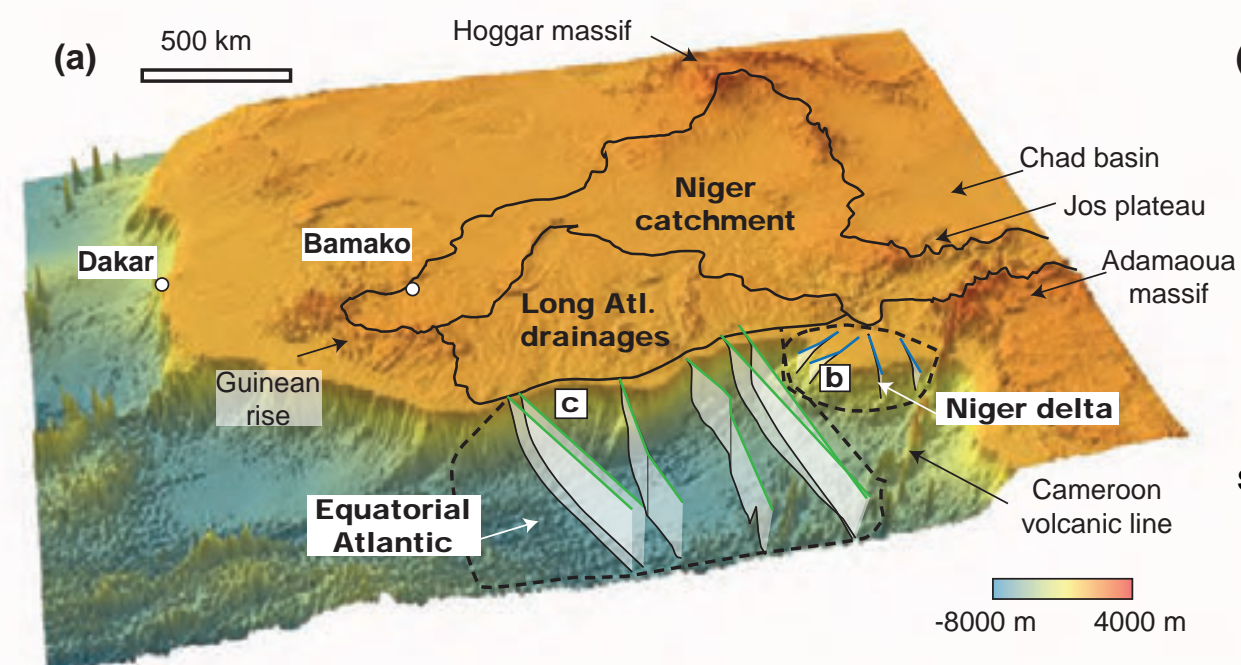

\section{(b) Niger delta}

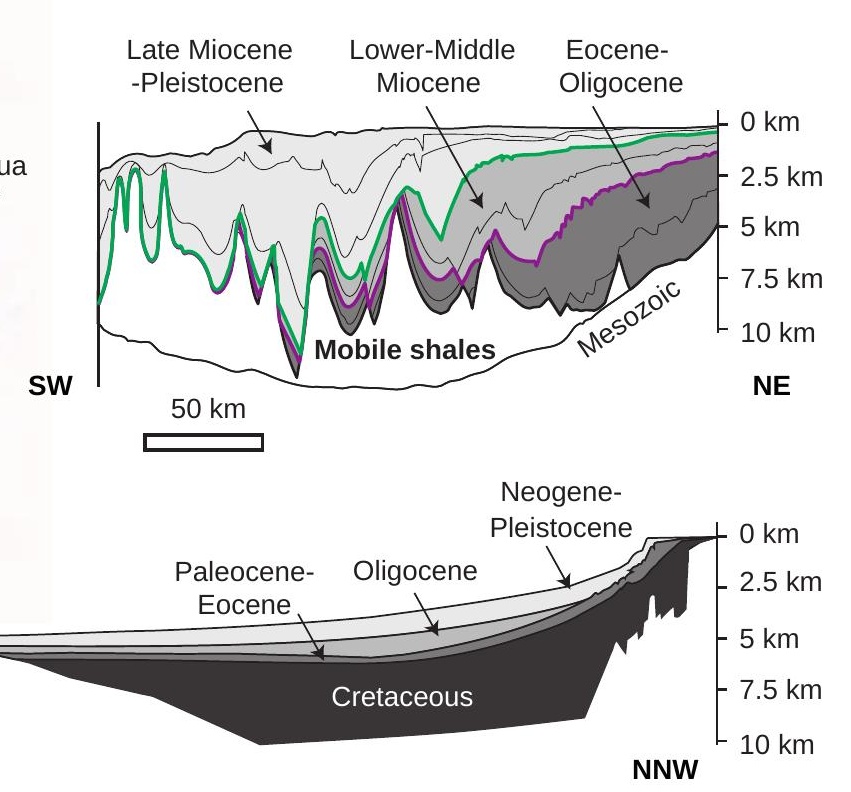

(c) Offshore Ivory Coast

SSE

(d)

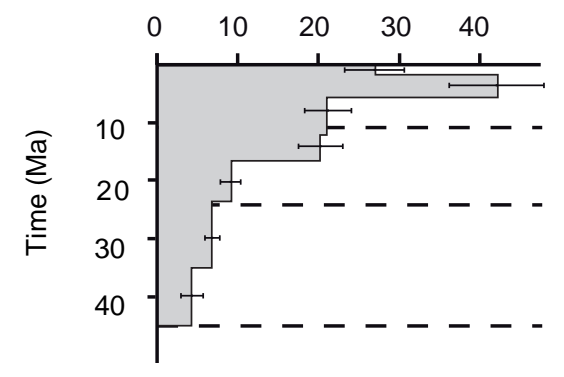

Accumulation rates $\left(10^{3} \mathrm{~km}^{3} \mathrm{Myr}^{-1}\right)$

(e) Niger delta re-sampled

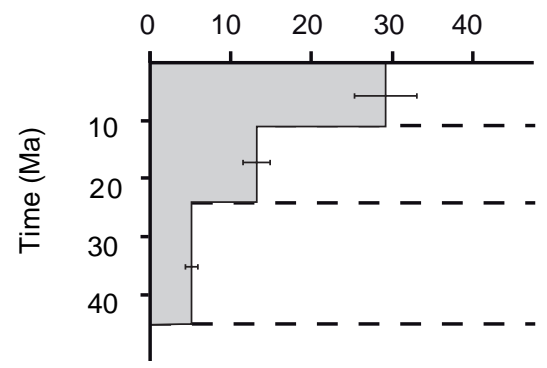

(f) Equatorial Atlantic

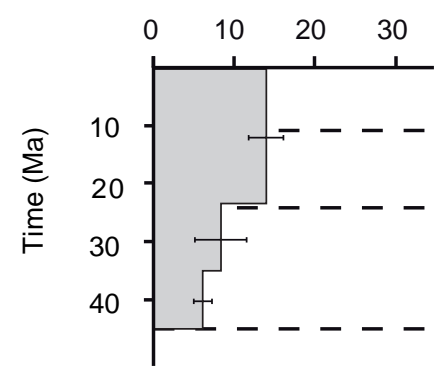

Grimaud et al., Fig. 9 